Studia z Dziejów Średniowiecza, t. 24, 2020

\author{
Mateusz Szuba \\ (Uniwersytet Gdański)
}

https://orcid.org/0000-0002-1085-7345

\title{
Osoby duchowne w otoczeniu i czynnościach prawnych księcia gdańskiego Warcisława II
}

\author{
https://doi.org/10.26881/sds.2020.24.10
}

Keywords: The history of the Church, Sobiesławice dynasty, East Pomerania, canon groups, Pomeranian clergy

Celem artykułu jest omówienie aspektów dotyczących duchownych posługujących na obszarze władzy księcia gdańskiego Warcisława II z dynastii Sobiesławiców w okresie jego rządów w latach 1266-1269/70. W obszar tych badań wchodzi więc także otoczenie duchowne wspomnianego władcy. Jak stwierdzono w literaturze, pojęcie otoczenia w przyjmowanym przez historyków określonym i szerszym znaczeniu nie było używane w średniowieczu, jest więc terminem sztucznym i jego zakres zależy od wyboru badacza $^{1}$. W niniejszej pracy do tej grupy zalicza się wszystkie osoby duchowne występujące w źródłach u boku Warcisława II i jednocześnie związane z ośrodkami podlegającymi jego władzy, szczególnie centrami administracyjnymi (Gdańsk, prawdopodobnie Słupsk). Jak bowiem się zakłada i co zostanie wykazane, duchowni byli w tych miejscach z różnych względów współpracownikami władcy. Są to więc głównie osoby wymienione w listach świadków dokumentów powyższego księcia (a więc przy jego czynnościach prawnych)

1 J. Sperka, Otoczenie Wtadystawa Opolczyka w latach 1370-1401. Studium o elicie władzy $w$ relacjach $z$ monarcha, Katowice 2006, s. 15-16; B. Czwojdrak, Zofia Holszańska. Studium o dworze i roli królowej w późnośredniowiecznej Polsce, Warszawa 2012, s. 92-93, gdzie też przegląd definicji otoczenia. 
i określone tam wyraźnie odpowiednim tytułem jako duchowne. Kolejnym kryterium jest informacja w źródle o bezpośredniej podległości danego duchownego księciu, np. określeniem „nasz” - „nostri”, lub posłudze danego duchownego w miejscu na obszarze władzy księcia Warcisława II. Kryterium terytorialne ma zastosowanie w wypadku dokumentu wystawionego przez Mściwoja II w 1269 r. w Słupsku, gdzie występują zarówno dostojnicy Warcisława II, jak i on sam. Należy jednocześnie pamiętać, że nie wszyscy znani duchowni mogli należeć do najbliższego otoczenia władcy, dlatego też w tytule wyróżniono osoby jedynie posługujące na terenie jego władzy w mniejszych ośrodkach. Ujęto także duchownych, wobec których spełnienie powyższych kryteriów jest dyskusyjne. Wybór tych osób zostanie uzasadniony.

Powyższy temat jak dotąd nie był podejmowany przez badaczy całościowo. W sposób syntetyczny temat duchowieństwa wschodniopomorskiego opracował ks. Władysław Łęga, jego pracę trzeba jednak uznać za przestarzałą ${ }^{2}$ Dokładnego omówienia doczekał się natomiast m.in. skład kapituł kościelnych w Gdańsku, czego dokonał Kazimierz Jasiński, włącznie z badaniami nad chronologią miejscowych kościołów ${ }^{3}$. Również XIII-wieczne dzieje kościołów w Słupsku i ich obsady były przedmiotem dyskusji prowadzonych przez Józefa Sporsa i Barbarę Popielas-Szultkę . Biogramy, pióra Kazimierza Jasińskiego i Błażeja Śliwińskiego, mają także najważniejsi duchowni tego okresu, jak kapelan Herman i kanclerz Luder ${ }^{5}$. Działalnością drugiego z wymienionych zajęła się

2 W. Łęga, Społeczeństwo i państwo gdańsko-pomorskie w XII i XIII w., Poznań 1956, s. 59-64.

3 K. Jasiński, Z problematyki trzynastowiecznego Gdańska. Kościoły gdańskie, ZH 1974, t. 39, z. 3, s. 37-66; idem, Chronologia kościołów gdańskich XII i XIII wieku. Uwagi metodyczne, cz. I, ZH 1985, t. 50, z. 1, s. 55-77 (szczególnie s. 63-71); cz. II, ibidem, z. 2, s. 69-89; idem, Gdańska grupa kanonicka-karta z dziejów organizacji kościelnej średniowiecznego Gdańska [w:] Gdańsk średniowieczny w świetle najnowszych badań archeologicznych i historycznych, red. H. Paner, Gdańsk 1998, s. 72-79. Ostatnio badania K. Jasińskiego podsumował B. Śliwiński, Pomorze Wschodnie w okresie rzadów księcia polskiego Wtadysława Łokietka w latach 1306-1309, Gdańsk 2003, s. 181-186 (wyd. 2, Oświęcim 2016, s. 122-126).

4 Literatura na ten temat jest bardzo rozproszona. Zebrała ja B. Popielas-Szultka, Rozwój przestrzenny Stupska od IX do poczatku XIV wieku, ,Zeszyty Kulickie” 1999, nr 1, s. 162-182. Dokładne pozycje niżej, przy omówieniu duchownych słupskich.

5 B. Śliwiński, Herman [w:] SBPN, t. 2, s. 191-192; K. Jasiński, Luder (I pot. XIII w. - po 1285) [w:] SBPN, t. 3, s. 90-91. 
w ostatnich latach także Agnieszka Gut, która zbadała problem kancelarii władców wschodniopomorskich i jego personelu ${ }^{6}$, a Paweł Samól dzieje kościoła grodowego w Gdańsku z uwzględnieniem roli duchownych tej świątyni ${ }^{7}$. Całościowego omówienia doczekały się także na szerszym tle stosunki Sobiesławiców z Kościołem oraz składy konwentów zakonnych Pomorza Wschodniego ${ }^{8}$. Również autor niniejszego artykułu omówił już wcześniej w innym miejscu problematykę osób duchownych z otoczenia Warcisława II, ograniczoną wszakże tylko do osób wywodzących się lub działających na ziemiach słupskiej i białogardzkiej ${ }^{9}$. Badania na temat opisanych tam postaci, pochodzących ze wspomnianych ziem, zostana więc powtórzone, ale i pogłębione.

Poniżej podjęto próbę weryfikacji i uzupełnienia dotychczasowych ustaleń. W tym celu odtworzono, na podstawie dostępnych źródeł, kariery kolejnych duchownych z poszczególnych ośrodków - pierwszym jest Gdańsk. Następnie dokładniej omówiono osobę Michała, określanego w źródłach jako „prepositus de Saulin”, który był już opisywany przez autora we wspomnianej pracy. $\mathrm{Na}$ koniec zaś powtórzono wyniki badań nad duchownymi ze Słupska ${ }^{10}$, choć z poszerzeniem kwestii politycznych i uwzględnieniem problematyki podziałów terytorialnych. Zaznaczyć bowiem należy, że przynależność terytorialna tego ośrodka, zarówno do księstwa Warcisława II, jak i w odniesieniu do późniejszego okresu, budzi w nauce dyskusje, czego wyrazem sa nowe hipotezy. Dotyczy

6 A. Gut, Urzad kanclerza za panowania księcia wschodniopomorskiego Mściwoja II (1266-1294), SŹ 2005, t. 43, s. 53-60; eadem, Średniowieczna dyplomatyka wschodniopomorska: dokumenty i kancelarie Pomorza Wschodniego do 1309 r., Szczecin 2014, s. 101-117.

7 P. Samól, Kościót grodowy w Gdańsku. Studium z pogranicza historii $i$ architektury [w:] Pielgrzymi, pogrobowcy, prebendarze, red. B. Śliwiński, Malbork 2009 (,Studia z Dziejów Średniowiecza” nr 15), s. 173-201.

8 M. Smoliński, Relacje ksiażat Pomorza Wschodniego z dynastii Sobiesławiców $z$ Kościołem [w:] 1050. rocznica Chrztu Polski, red. K. Lewalski, Gdańsk 2016, s. 63-131; Spisy członków konwentów zakonnych z Pomorza Gdańskiego do 1309 roku, oprac. D.A. Dekański, Gdańsk [1994]. Dorobek tego badacza na temat wschodniopomorskich zgromadzeń zakonnych zebrał W. Długokęcki, Dariusz Aleksander Dekański (1961-2018) [w:] Stownik biograficzny historyków Uniwersytetu Gdańskiego, red. E. Koko, Z. Opacki, Gdańsk 2020, s. 93-96.

9 M. Szuba, Możni z ziemi białogardzkiej i stupskiej $w$ otoczeniu księcia gdańskiego Warcistawa II, „Argumenta Historica. Czasopismo Naukowo-Dydaktyczne” 2017, nr 4, s. 127-141.

10 Ibidem, s. $132-135$. 
to również dziejów ziemi białogardzkiej. Przedstawiając kolejne osoby, zwrócono uwagę na ich pochodzenie oraz możliwe znaczenie polityczne. Odnośnie do tej ostatniej kwestii zwrócono uwage na to, czy kolejne osoby działały także na dworze poprzednika Warcisława II na tronie gdańskim, czyli Świętopełka, oraz u boku następcy - Mściwoja II. Wzór stanowi metoda zastosowana przez historyków w badaniach nad możnymi w kontekście ich związków z wymienionymi władcami oraz postawami w okresie wojny domowej z lat 1269-1271 ${ }^{11}$, a także stosunków innych Sobiesławiców z rycerstwem ${ }^{12}$. Jej zastosowanie wydaje się uzasadnione, gdyż według dotychczasowej opinii historyków pełnienie przez niżej omówionych duchownych funkcji zależało od woli księcia. Wynikało to albo z dworskiego charakteru ich służby (kapelani), albo z prawa patronatu nad częścią świątyń. W tym ostatnim wypadku władca miał prawo powoływać miejscowych duchownych za zgoda biskupa ${ }^{13}$. Pewne znaczenie, na co zreszta wskazywano w literaturze, mogły mieć także związki rodzinne, konieczne więc jest także uwzględnienie w niektórych przypadkach metody genealogicznej, podobnie jak we wspomnianych pracach ${ }^{14}$. Podjęcie tych badań

11 Metodę badań zaczerpnięto z następujących pozycji: K. Jasiński, Wojna domowa na Pomorzu Gdańskim w latach 1269/1270-1272 (ze szczególnym uwzględnieniem roli rycerstwa i możnowładztwa) [w:] Społeczeństwo Polski średniowiecznej, red. S.K. Kuczyński, Warszawa 1985; B. Śliwiński, Rola polityczna możnowładztwa na Pomorzu Gdańskim w czasach Mściwoja II, „Zeszyty Naukowe UG, Rozprawy i Monografie" 1987, nr 86, szczególnie s. 21-91. Literatura dotycząca wojny domowej z lat 1269-1271 zob. niżej. Podobną metodę badania postaw politycznych osób duchownych zastosował także J. Bieniak, Wielkopolska, Kujawy, ziemie łęczycka i sieradzka wobec problemu zjednoczenia państwowego w latach 1300-1306, RTNT 1969, R. 64, z. 2, szczególnie s. 8-19, 55, 73-77, 99-100, 126-134, 145-147, 183-191, 284-286.

12 P. Oliński, Otoczenie księcia lubiszewsko-tczewskiego Sambora II [w:] Krzyżowcy, kronikarze, dyplomaci, red. B. Śliwiński, Gdańsk 1997 („Gdańskie Studia z Dziejów Średniowiecza”, nr 4), s. 115-146.

13 E. Wiśniowski, Rozwój organizacji parafialnej w Polsce do czasów reformacji [w:] Kościót w Polsce, t. 1: Średniowiecze, red. J. Kłoczowski, Kraków 1966, s. 285-286; W. Abraham, Poczatki prawa patronatu w Polsce, Lwów 1889, s. 11-12. Dokładniejsze omówienie zasad i okoliczności powoływania duchownych przez władcę przy poszczególnych przypadkach. W literaturze, zapewne ze względu na małą liczbę źródeł, nie sprecyzowano statusu prawnego i własnościowego omówionych w tej pracy kościołów gdańskich i słupskich, tj.: czy były to kościoły prywatne, czy władcy Gdańska byli tylko ich fundatorami. Nieliczne przekazy zdają się wskazywać na to drugie (np. Świętopełk musiał uzyskać zgodę biskupa kujawskiego na przekazanie kościoła św. Mikołaja dominikanom w 1227 r. - P 34).

14 Zob. przyp. 11; J. Bieniak, Wielkopolska, Kujawy..., szczególnie s. 8-19, 284-286. 
pozwoli więc nie tylko na uchwycenie zmian składu osobowego, ale również możliwych relacji między księciem gdańskim i duchownymi, a więc orientacji politycznej tych ostatnich i ich wpływu politycznego na władzę książęca.

Przystępując do tematu, należy zarysować ogólne tło historyczne. Warcisław II (ur. około 1236 r.) był młodszym synem księcia gdańsko-pomorskiego Świętopełka i bratem Mściwoja II. Władzę w Gdańsku objął po śmierci ojca, która nastapiła 10 lub 11 stycznia 1266 r., podczas gdy Mściwoj II dowodnie już w 1264 r. rządził w dzielnicy ze stolica w Świeciu nad Wisła. Przyczyny takiego podziału państwa Świętopełka pozostają dyskusyjne, obecnie wskazuje się i to w odniesieniu do obu części tego władztwa, na duże znaczenie możnowładztwa ${ }^{15}$. Ono właśnie, zgodnie z przekazem Kroniki oliwskiej, wyniosło Warcisława II na księcia w Gdańsku ${ }^{16}$. Jego księstwo obejmowało z pewnością ziemię gdańską. Brakuje natomiast jasnych przesłanek co do tego, czy sprawował władzę w ziemi słupskiej i sławieńskiej, choć historycy przeważnie wskazuja, że również te obszary należały do Warcisława II. Zostanie to omówione niżej. Ostatnie z wymienionych terytoriów zostało jednak już latem 1266 r. opanowane przez księcia Pomorza Zachodniego Barnima I. Niejasna pozostaje także przynależność dzielnicy, której głównym ośrodkiem była Białogarda nad Łeba. Nie wiadomo bowiem, kiedy dokładnie ustapił z niej brat Świętopełka, Racibor. Do Warcisława II nie należała także dzielnica tczewska, rządzona przez kolejnego ze stryjów - Sambora II. Mściwoj II zaś, jak wspomniano, rządził w dzielnicy świeckiej. Należała do niej także ziemia raciąsko-szczycieńska, gdzie starszy syn Świętopełka prawdopodobnie miał swoją pierwszą

15 O dążeniach możnowładztwa ziemi świeckiej zob. ostatnio B. Śliwiński, Mściwoj II (1224-1294). Ksiaże wschodniopomorski i gdański, Warszawa 2016, s. 87-96.

16 Chronica Olivensis auctore Stanislao, Abbate Olivensi, wyd. W. Kętrzyński [w:] MPH, t. 6, Kraków 1893, s. 313; M. Smoliński, Świętopetk gdański, Poznań 2016, s. 281, 286-288; idem, Primogenitus et dilectissimus. Świętopetk gdański $i$ jego synowie: Mściwoj II $i$ Warcisław II [w:] Ojcowie i synowie. O tron, władzę, dziedzictwo, red. B. Możejko i A. Paner, Gdańsk 2018, s. 65-100, szczególnie s. 71-74, 96-100, gdzie wcześniejsza dyskusja i szerokie omówienie problemu na tle porównawczym; M. Szuba, Data narodzin i pozycja późniejszego księcia gdańskiego Warcisława II do 1266 roku, „Studia z Dziejów Średniowiecza” 2017, nr 21, s. 213-216; idem, Stosunki zewnętrzne $i$ upadek księcia gdańskiego Warcisława II [w:] Gdańsk jest kluczem do wszystkiego. W poszukiwaniu genius loci miasta, red. A. Siekierska i W. Borzestowski, Kraków 2019, s. 195-200. 
dzielnicę ${ }^{17}$. Ów podział dzielnicowy Pomorza Wschodniego nie trwał jednak długo. Jak się przypuszcza, konflikt o stołeczny Gdańsk oraz o prymat władzy między braćmi, a także sprzeczne dążenia możnowładztwa doprowadziły do wojny domowej rozpoczętej w 1269 r. Podczas tego konfliktu Mściwoj II pozbawił władzy i wypędził zarówno Sambora II, jak i Warcisława II na Kujawy, gdzie ten ostatni zmarł 9 maja 1271 r. Starszy syn Świętopełka, jak się przyjmuje, swój sukces zawdzięczał poparciu czynnika społecznego w postaci możnowładztwa ${ }^{18}$. W literaturze wskazywano także na zaufanych duchownych Mściwoja II, którzy być może rozwijali swe kariery już przed wojną domowa. Istotne wydaje się więc zbadanie podobnych kwestii w wypadku Warcisława II, także w odniesieniu do wspomnianego problemu objęcia przez niego władzy.

Podstawa źródłowa omawianego tematu jest skromna. Duchowni pochodzący z obszaru będącego pod panowaniem Warcisława II pojawiają się w jego otoczeniu z pewnością tylko na dwóch, z pięciu

17 Na temat podziałów dzielnicowych zob. J. Spors, Podziały administracyjne Pomorza Gdańskiego i Stawieńsko-Stupskiego od XII do poczqtku XIVw., Słupsk 1983, s. 283-293; B. Śliwiński, Gdzie znajdowata się pierwsza dzielnica księcia Mściwoja II wschodniopomorskiego [w:] A Pomerania ad ultimas terras. Studia ofiarowane Barbarze Popielas-Szultce $w$ sześćdziesiata piata rocznice urodzin $i$ czterdziestolecie pracy naukowej, red. J. Sochacki i A. Teterycz-Puzio, Słupsk 2011 s. 44-55; idem, Mściwoj II..., s. 68-74, 104. Szersza literatura niżej, przy omawianiu kwestii ziem białogardzkiej i słupskiej.

18 Przyczyny i przebieg wojny domowej ostatnio szeroko omówił z podaniem wcześniejszej literatury B. Śliwiński, Mściwoj II..., s. 102-189; por. E. Rymar, Mściwoj II jako lennik margrabiów brandenburskich (w latach 1269-1273), „Studia z Dziejów Średniowiecza” 2019, t. 23, s. 216-244; Kujot, cz. 1, s. 866-873, 937-952; P. von Niessen, Geschichte der Neumark im Zeitalter ihrer Entstehung und Besiedlung, Landsberg a. W. 1905, s. 216-223; K. Zielińska, Zjednoczenie Pomorza Gdańskiego z Wielkopolska pod koniec XIII w. Umowa kepińska 1282 r., RTNT 1968, R. 73, z. 3, s. 18-34; B. Włodarski, Świętopetk i Mściwój II (Z dziejów Pomorza Gdańskiego w XIII wieku), ZH 1968, t. 33, z. 3, s. 78-86; J. Powierski, Uktad kamieński (1264) na tle stosunków między ksiażętami Pomorza, Krzyżakami i Prusami w latach sześćdziesiatych XIII wieku, „Rocznik Olsztyński” 1968, t. 8, s. 11-31 (gdzie uwzględniono i zaznaczono rolę polityczną duchownych); J. Spors, Podziaty..., s. 293-294; E. Rymar, Walka o Pomorze Gdańskie w latach 1269-1272, RG 1987, t. 47, z. 1, s. 5-30; M. Derwich, Tyniecka zgoda i wyszogrodzka wróżda. $O$ dwóch konfliktach wewnętrznych $w$ Polsce średniowiecznej XII $i$ XIII wieku, KH 1988, t. 95, z. 2, s. 15-23; A. Bugaj, Datacja przekazów Piotra z Dusburga o wojnie krzyżacko-pomorskiej z 1266 r. [w:] Kopijnicy, szyprowie, tenutariusze, red. B. Śliwiński, Gdańsk 2002 („Gdańskie Studia z Dziejów Średniowiecza”, nr 8), s. 44 et seq.; M. Smoliński, Świętopełk gdański..., s. 281-288; idem, Primogenitus et dilectissimus..., s. 65-100; M. Szuba, Stosunki..., s. 195-219. 
zachowanych, dokumentach tego księcia. Po raz pierwszy występują na liście świadków przywileju Warcisława II dla lubeczan z 17 maja 1268 r. ${ }^{19}$, następnie w konfirmacji dóbr klasztoru w Bukowie z 8 sierpnia tego roku, gdzie pojawia się też Michał „de Saulyn”" Duchowni ze Słupska występuja w wystawionym w tym grodzie 3 maja 1269 r. dyplomie Mściwoja II, również potwierdzającym dobra wspomnianego klasztoru. Dokument ten stanowi potwierdzenie wymienionego przywileju Warcisława II, który to książę tym razem otwierał listę świadków dokumentu brata ${ }^{21}$.

W wypadku niemal wszystkich omawianych dokumentów osoby należące do stanu duchownego otwierały listę świadków towarzyszących Warcisławowi II. Wyjątek stanowi przywilej dla Lubeki z 17 maja 1268 r., gdy występuja pomiędzy urzędnikami gdańskimi. Spośród duchownych najczęściej, bo dwukrotnie, wymieniani byli Herman i Wacław (Unisław), obaj na dokumentach wystawionych w Gdańsku w 1268 r. Zostali tutaj określeni jako kapelani książęcy albo posługujący w miejscowym kościele grodowym $^{22}$. Świątynia ta najprawdopodobniej nosiła wezwanie Maryi. Był to jeden z trzech znanych XIII-wiecznych gdańskich kościołów, obok tych pw. św. Mikołaja (dominikańskiego) i św. Katarzyny (miejskiego - samorządowego) ${ }^{23}$. Większość

$19 \mathrm{P}, \mathrm{nr} 232$. Dokument ten zachował się do dnia dzisiejszego wraz z pieczęcia w Archiv der Hansestadt Lübeck, sygn. Pomeranica 019. Potwierdza to informacje M. Perlbacha [w:] P, s. 187; pisała o tym też A. Gut, Średniowieczna..., s. 118, przyp. 113. W niniejszej pracy autor korzystał ze skanu przesłanego ze wspomnianej instytucji. Warto dodać, że w podobny sposób zachował się wcześniejszy przywilej Warcisława II dla lubeczan z 10 maja 1267 r. i przywieszona doń pieczęć (P, nr 220; Pomeranica 018) oraz pięć dokumentów Świętopełka dla tego samego podmiotu (Pomeranica $006=\mathrm{P}, \mathrm{nr} 33 ; 007=\mathrm{P}, \mathrm{nr} 74 ; 008=\mathrm{P}, \mathrm{nr} 102 ; 011=\mathrm{P}, \mathrm{nr} 154 ; 016$ $=\mathrm{P}, \mathrm{nr} 200$ ), z których tylko jeden (Pomeranica 007) zachował się bez pieczęci, ale ze sznurem. Również tutaj potwierdzenie znajdują informacje M. Perlbacha [w:] P, s. 29, 61, 87, 130, 169, 179. Przetrwały również późniejsze dokumenty Władysława Łokietka, Święcy i Rady miasta Gdańska dla Lubeki (P, nr 564, 565, $580,581,584,586)$. Wymagają one jednak osobnego i szerszego omówienia. Skany pozyskano w ramach projektu subwencji budżetowej Wydziału Historycznego Uniwersytetu Gdańskiego dla młodych naukowców i uczestników studiów doktoranckich, nr projektu: BMN 539-U100-B087-20.

$20 \mathrm{P}, \mathrm{nr} 235$.

$21 \quad \mathrm{P}, \mathrm{nr} 239$.

22 P, nr 232 („Hermannus et Winceslaus capellani nostri”), 235 (,Ventzlaus capellani castri Dantzik, Hermannus sacerdos ibidem").

23 O gdańskich kościołach w XIII w. zob. szczególnie K. Jasiński, Chronologia..., cz. I, s. 63-77; cz. II, s. 69-81; idem, List Mściwoja II do margrabiów..., s. 38-42; 
badaczy uznaje wspomnianych duchownych za członków grupy kanonickiej działającej przy kościele grodowym, która najprawdopodobniej nie miała charakteru kolegiaty. Uznaje się, że pierwsze wzmianki o gdańskim zgromadzeniu kanonickim pochodzą już z 1227 r. ${ }^{24}$ Grupy takie były znane na ziemiach polskich, a także na Pomorzu Zachodnim już w XII w. Powstawały przy świątyniach i miały na celu przede wszystkim uczestnictwo we wspólnym, określonym regułami życiu religijnym. Później dopiero kanonicy zaczęli wypełniać posługi dla ludności, czyli duszpasterskie, oraz dla władzy, jako aparat administracyjny ${ }^{25}$. Dotyczyło to także gdańskiej grupy, jak się bowiem wskazuje, to właśnie ona była związana z książętami i dworem, a także odgrywała istotną rolę w jego działalności, uczestnicząc $\mathrm{w}$ administrowaniu państwem czy prowadząc kancelarię ${ }^{26}$. Jak jednak stwierdzono w literaturze, powyższe znaczenie gdańscy kanonicy utrzymywali za rządów Świętopełka i Warcisława II, utracili zaś za Mściwoja II. Kazimierz Jasiński wskazał, że w dokumentach księcia Mściwoja gdańscy kanonicy występują rzadziej, co przyjął za wyraz ochłodzenia wzajemnych stosunków. Agnieszka Gut zauważyła zaś, na podstawie dokładnych badań, iż gdańska grupa po 1270 r. nie stanowiła już książęcej kancelarii, zastapili ją w tej roli kanonicy świeccy $^{27}$. Zdaniem Błażeja Śliwińskiego ta utrata znaczenia nie

idem, Gdańska grupa..., s. 75-83 (szczególnie s. 82) oraz pozostałe prace tego badacza, zob. przyp. 3.

${ }^{24}$ K. Jasiński, Z problematyki..., s. 38-46; idem, Chronologia... cz. I, s. 63-66; idem, Gdańska grupa..., s. 72-75, gdzie starsza literatura i dyskusja z badaczami opowiadajacymi się za kolegiatą.

25 T. Lalik, Zagadnienie „vitae communis” kapitut polskich XII w. [w:] idem, Studia średniowieczne, wyd. S. Trawkowski, s. 427; J. Szymański, $Z$ zagadnień vitae canonicae $w$ Polsce XII-XIII wieku, „Roczniki Teologiczno-Kanoniczne” (dalej: RTK) 1963, t. 10, z. 4, s. 145-148; idem, Biskupstwa polskie w wiekach średnich. Organizacja i funkcje [w:] Kościót w Polsce, t. 1:, Średniowiecze, red. J. Kłoczowski, Kraków 1966, s. 199-205; idem, Kanonikat świecki w Małopolsce od końca XI do połowy XIII wieku, Lublin 1995, s. 82-88 (o stosunkach kanoników z księciem i możnowładztwem), 102-103, 121-123.

26 P. Kriedte, Die Herrschaft der Bischöfe von Wtoctawek in Pommerellen von den Anfängen bis zum Jahre 1409, Göttingen 1974, s. 62; K. Jasiński, Gdańska grupa kanonicka..., s. 74; A. Gut, Średniowieczna dyplomatyka..., s. 114-115; M. Smoliński, Świętopetk gdański..., s. 159-162. O znaczeniu politycznym wschodniopomorskich kanoników wspomniał także J. Szymański, Kanonikat świecki..., s. 102, oparł się jednak na błędnej przesłance.

27 K. Jasiński, Gdańska grupa kanonicka..., s. 83; A. Gut, Średniowieczna dyplomatyka..., s. 110-117. 
miała swojego źródła w konflikcie między Świętopełkowicami, ale w nieco późniejszym zajęciu Gdańska przez margrabiego brandenburskiego Konrada, którego poparli wtedy mieszczanie, a być może i część skłóconych na tym tle duchownych kościoła grodowego. Za ten czyn spotkałaby ich ze strony Mściwoja II niełaska. Przesłanką byłaby tu nieobecność części duchownych znanych z czasów rządów Warcisława II u boku nowego władcy ${ }^{28}$. Ustalenia wymienionych badaczy wydają się generalnie słuszne, w niektórych kwestiach można je jednak uzupełnić.

Co istotne, Herman oraz być może także Wacław/Unisław posługiwali na gdańskim grodzie już w czasach młodości Warcisława II. Herman, ze względu na pierwszeństwo na listach świadków, jest uznawany za przewodniczącego wspomnianej grupy. Pełnił taką funkcję już w 1247 r., co świadczyłoby o jego znaczeniu na dworze Świętopełka. Uczestniczył w wielu ważnych wydarzeniach - przypuszcza się, że brał m.in. udział w rokowaniach z klasztorem w Darguniu, dotyczących utworzenia jego filii, a później samodzielnego klasztoru w Bukowie. Biorąc powyższe kryteria pod uwagę, można by przyjąć, że również za czasów Warcisława II Herman utrzymał swą funkcję i znaczenie. Sprzyjałaby temu być może długa znajomość z władca. Błażej Śliwiński wskazał na możliwość identyfikacji omawianego Hermana z kapelanem Świętopełka o tym imieniu, obdarowanym przez księcia w 1240 r. w Słupsku wsią Ryczewo ${ }^{29}$. Jest jednak bardziej prawdopodobne, że był to późniejszy duchowny miejscowego kościoła św. Mikołaja, o którym będzie jeszcze mowa. Za taką identyfikacja przemawiają bowiem względy terytorialne. Związków kapelana gdańskiego z zachodnimi obszarami państwa Świętopełka, tj. z ziemią sławieńską lub słupska, nie musi także dowodzić jego przypuszczalne uczestnictwo w fundacji klasztoru w Bukowie. Mogło ono bowiem wynikać z roli, jaką Herman z Gdańska odgrywał w otoczeniu księcia ${ }^{30}$. Wspomniany badacz doszukiwał się także Hermana w kapelanie Mściwoja II o tym samym imieniu, wzmiankowanym w Gdańsku

28 B. Śliwiński, Mściwoj II..., s. 177-178. O zajęciu Gdańska przez Brandenburczyków i wydarzeniach z lat 1271-1272 zob. ibidem, s. 162-187; E. Rymar, Walka o Pomorze..., s. 5-30; idem, Mściwoj II jako lennik..., s. 228-235; K. Jasiński, List Mściwoja II do margrabiów brandenburskich. Uwagi polemiczne i krytyczne [w:] Pomorze słowiańskie i jego sqsiedzi, red. J. Hauziński, Gdańsk 1995, s. 31-43.

29 P, nr 70; B. Śliwiński, Herman [w:] SBPN, t. 2, s. 191.

30 Autor uzasadnił to już wcześniej, zob. M. Szuba, Możni..., s. 132-133. 
w 1277 r., wskazując jednocześnie, że duchowny ten utracił wtedy swoje znaczenie, przypuszczalnie z powodu poparcia Świętopełka w konflikcie z Mściwojem II $^{31}$.

Peter Kriedte natomiast utożsamił kapelana gdańskiego Hermana z majacym to samo imię plebanem ze Świecia nad Wisła i członkiem miejscowej grupy kanonickiej, a także archidiakonem pomorskim $^{32}$. Kazimierz Jasiński początkowo także utożsamiał Hermanów z obu ośrodków ${ }^{33}$. Później jednak odróżnił kanonika świeckiego, z którym utożsamiał archidiakona, od duchownego gdańskiego ${ }^{34}$, co poparła nowymi dowodami A. Gut ${ }^{35}$. Wskazała przede wszystkim, że identyfikację Hermana z 1277 r. z kapelanem gdańskim o tym imieniu osłabia zbyt długi okres od pojawienia się tego ostatniego, co miało miejsce w 1268 r. Bardziej prawdopodobne byłoby więc utożsamianie duchownego z 1277 r. z kanonikiem świeckim, który z kolei występował od 1270 r. Kolejnym argumentem byłoby umieszczenie Hermana w dwóch $\mathrm{z}$ trzech dokumentów z 1277 r. ${ }^{36}$, oddzielając od osób kojarzonych z kancelarią książęca, a więc przypuszczalnie należących do gdańskiej grupy kanonickiej. Nie jest to jednak, jak wskazała sama badaczka, przesłanka przesądzajaca. Końcowy wniosek wzmacniałoby natomiast wymienienie Hermana na pierwszym miejscu wśród duchownych, jako najbliższego współpracownika Mściwoja II. Wskazywałoby to bowiem na posługę tego kapelana w Świeciu, gdzie wspomniany książę miał swoją główną siedzibę. Agnieszka Gut zwróciła bowiem uwagę, że także Herman pleban ze Świecia został wymieniony na pierwszym miejscu w dokumencie z 8 września 1274 r., wystawionym prawdopodobne w Słupsku ${ }^{37}$. Podobnie można wytłumaczyć obecność na drugim miejscu, a więc pomiędzy Hermanem a członkami kancelarii, plebana kościoła św. Katarzyny w Gdańsku, choć przedstawiciele tej świątyni do tej pory występowali w źródłach

31 P, nr. 287, 288, 289; B. Śliwiński, Herman ..., t. 2, s. 191-192.

32 P. Kriedte, Die Herrschaft..., s. 62-64.

33 K. Jasiński, Z problematyki..., s. 44, przyp. 48.

34 K. Jasiński, Chronologia, cz. I..., s. 66.

35 A. Gut, Średniowieczna..., s. 112-114. Problem sprawowania przez kanonika świeckiego Hermana funkcji archidiakona nie należy do tematu niniejszej pracy, niemniej jest to mało prawdopodobne, z podobnych powodów jak w wypadku kapelana Wacława/Unisława, zob. niżej.

$36 \mathrm{P}, \mathrm{nr} 287,288$.

37 P, nr 267; A. Gut, Średniowieczna..., s. 112-114; por. P. Samól, Kościót grodowy..., s. 178-181. 
za duchownymi kościoła grodowego. Plebanem tym był bowiem Luder - niżej zostanie przedstawiony - również bliski współpracownik, a wkrótce, bo od 1279 r. - kanclerz Mściwoja II. Duchowny ten, zdaniem B. Śliwińskiego, miał przejąć rolę członków grupy kanonickiej przy kościele grodowym, w tym Hermana, którzy nie zyskali zaufania u wspomnianego władcy. Powodem byłaby prawdopodobnie wcześniejsza bliska współpraca powyższego grona duchownych z Warcisławem II $^{38}$. Z tego więc wynika, że Hermana z $1277 \mathrm{r}$. raczej nie można utożsamiać z duchownym księcia gdańskiego z lat 1267 i 1268. Ten drugi nie działałby więc na dworze Mściwoja II, być może będąc przez tego księcia odsuniętym od życia politycznego.

Podobna kariera rysuje się w wypadku Wacława/Unisława. Imię tego duchownego pojawia się w latach $1247-1268$ w rożnych wariantach: Unislauus (1247), Wenceslauus (1248), Winceslaus, Ventzlaus $(1268)^{39}$. Max Perlbach w indeksie swojego kodeksu dyplomatycznego odróżnił pierwszą formę od pozostałych, zaliczając ją do wariantów imienia Unisław. Kolejne zaś uznał za odmiany imienia Wenzel. Odróżnił więc duchownego z 1247 r. od tego wzmiankowanego później ${ }^{40}$. Władysław Łęga utożsamiał je zaś i przyjął dla nich wspólną formę - Unisław. Podobnie K. Jasiński uznał, że powyższe informacje odnoszą się do jednej osoby, choć według tego badacza prawidłowa formą był nie Unisław, lecz Więcesław, odpowiadający imieniu Wacław ${ }^{41}$. Agnieszka Gut również przypisała powyższe imiona jednemu duchownemu, choć opowiedziała się raczej za stosowaniem formy Unisław, w odróżnieniu od imienia archidiakona Wacława, o czym niżej ${ }^{42}$. Wniosek o tożsamości wspomnianych osób badaczka oparła zapewne na podobieństwie sprawowanych przez nie funkcji. Może za tym przemawiać także utożsamienie przez badaczy innej postaci, w tym wypadku rycerza zachodniopomorskiego Więcława Długiego (Venzlaus Longe), występującego w dokumentach z lat 1282-1287, z osobami

38 B. Śliwiński, Herman..., s. 191-192. Również P. Samól, Kościót grodowy..., s. 180-181 opowiada się za utratą znaczenia kościoła grodowego.

$39 \mathrm{P}, \mathrm{nr} 101,108,232,235$.

40 P, s. 674-675.

41 W. Łęga, Społeczeństwo..., s. 61-62; K. Jasiński, Chronologia..., s. 66, przyp. 26.

42 A. Gut, Średniowieczna..., s. 111-112, szczególnie przyp. 57. Badaczka ta do analizy imienia zaliczyła też wzmiankę o archidiakonie z $1261 \mathrm{r}$. nazwanego Wnizlaus. W świetle jej dalszych ustaleń nie należy go jednak wiązać z gdańskim duchownym. 
pojawiającymi się także jako Venzlaus (Venceke) i Vnislaws (Vinslaus) ${ }^{43}$. Warto również zwrócić uwagę, że dokumenty z 1247 i 1248 r. były spisywane przez różnych pisarzy. Drugi z nich został najprawdopodobniej wytworzony przez odbiorcę, czyli klasztor w Darguniu. Podobnie mogło być w wypadku pierwszego dyplomu - z 1247 r., sporządzonego najpewniej dla klasztoru w Oliwie. Zawiera on bowiem niektóre cechy spotykane w formularzu oliwskich dokumentów ${ }^{44}$. Wyjaśniałoby to różnicę między pierwszą a druga forma imienia.

Można jednak podejrzewać, że wspomniane imiona gdańskiego duchownego odnoszą się do dwóch osób, szczególnie dlatego, iż pierwsza forma (Unislauus) różni się od pozostałych. Pogląd ten mógłby wspierać jeden z omawianych dokumentów, z 18 maja 1268 r. Występują w nim na liście świadków obok siebie kapelan Wacław i podkomorzy Unisław, obaj zapisani w różny sposób (Winceslauus i Vneslaus). Również na Pomorzu Zachodnim w XI w., w podobnym czasie, występowały osoby posługujące się imionami: Więcław i Unisław. Więcław, kasztelan woliński, pojawił się w dokumentach z lat 1163-1184 jako Venzeslaws, Venzenzlauo, Venezlao i Wenzeslauus, a więc $\mathrm{w}$ formach, pod jakimi występował gdański duchowny ${ }^{45}$. Unisław został natomiast zapisany w dokumentach z roku 1194 lub 1195 jako Vneslau ${ }^{46}$, czyli bardzo podobnie jak podkomorzy gdański. Wydaje się więc, iż za bardziej odpowiednią formę imienia należałoby uważać Więcesław/Więcław, tak jak uważali starsi badacze. Wniosek taki można wyciagnąć na podstawie tłumaczeń zlatynizowanych form omawianych imion, przyjętych niedawno przez Krzysztofa Guzikowskiego w odniesieniu do osób zamieszkujących Pomorze Zachodnie ${ }^{47}$. Pomimo tego imię Unisław, dotyczące gdańskiego duchownego, pojawia się tylko raz, w pierwszej wzmiance z 1247 r., i już później nie występuje. Kolejna informacja, z 1248 r., mówi już o osobie zwanej Wenceslauus, którą ze względu na podobieństwo imienia z większym

43 PU, Bd. II/2, nr 1225, s. 467; Bd. III/1, nr. 1414 i 1454, s. 5, 36; Bd. III/2, s. 539, 583-584 (indeks). W nawiasie podano formy uznane przez wydawcę za watpliwe. Zob. K. Guzikowski, Obce rycerstwo na Pomorzu Zachodnim do pocz. XIV w., wyd. 2, Szczecin 2015, s. 123.

44 A. Gut, Średniowieczna..., s. 144-145, 161.

45 PU, Bd. I, nr. 66, 74, 90, 97; Bd. I/2, s. 575; Bd. I, bearb. v. K. Conrad, nr 51a; K. Guzikowski, Obce rycerstwo..., s. 130.

46 PU, Bd. I, nr 126; K. Guzikowski, Obce rycerstwo..., s. 130.

47 K. Guzikowski, Obce rycerstwo..., s. 83, 85, 123, 130. 
prawdopodobieństwem można utożsamiać z późniejszym duchownym Warcisława II ${ }^{48}$. Jeśli dalej uznawać rok 1247 za czas pierwszej wzmianki o tym duchownym, Wacław/Unisław być może pełniłby, jak wskazała A. Gut, funkcję pisarza bądź notariusza. Świadczyłoby o tym użyte wobec niego i innego duchownego - Gozwina - określenie „clerici nostri”, które mogło także oznaczać ludzi wykształconych, którymi zapewne byli wszyscy książęcy kapelani ${ }^{49}$. W $1248 \mathrm{r}$. zaś był on wymieniony jako członek gdańskiej grupy kanonickiej ${ }^{50}$. Wcześniej m.in. Peter Kriedte oraz początkowo Kazimierz Jasiński i Jacek Maciejewski wiązali Wacława $\mathrm{z}$ archidiakonem pomorskim o tym samym imieniu, działajacym od 1240 r. ${ }^{51}$ Zostało to jednak podane w wątpliwość przez ostatniego z badaczy, a najpełniej przez A. Gut. Jacek Maciejewski wskazał na ogólniejsze wnioski P. Kriedtego - że biskup raczej nie wyznaczyłby na ten urząd jednego z duchownych pochodzacych ze wschodniopomorskich grup kanonickich, byli oni bowiem pod wpływem miejscowych książąt, co mogło się utrzymać także po nominacji. Hierarchowie włocławscy byli również często skonfliktowani z Sobiesławicami, dlatego powoływali archidiakonów ze swojego otoczenia ${ }^{52}$. Agnieszka Gut inaczej także zinterpretowała wyniki badań Stelli Marii Szacherskej, z których korzystali również wspomniani historycy. Wynikałoby z nich, że archidiakon Wacław był najprawdopodobniej tożsamy z wcześniejszym prepozytem z katedry św. Michała na Wawelu i notariuszem Konrada Mazowieckiego. Tym samym, zdaniem pierwszej z badaczek, niska funkcja, która pełniłby w Gdańsku - gdzie nie byłby nawet przewodniczącym grupy kanonickiej (a był nim najprawdopodobniej Herman) - nie odpowiadałaby przebiegowi kariery tego duchownego ${ }^{53}$.

$48 \mathrm{P}, \mathrm{nr} 101,108$

49 P, nr 101 (,Unislauus et Gozwinus clerici nostri”); A. Gut, Średniowieczna..., s. $111-112,116$;

50 P, nr 108 („Hermannus et Wenceslauus capellani de Gdanzk”).

51 P. Kriedte, Die Herrschaft..., s. 61; K. Jasiński, Chronologia, cz. I..., s. 66; J. Maciejewski, Dzialalność kościelna biskupa włocławskiego Wolimira (1252-1275), NP 1992, t. 78, s. 36-37, przyp. 59.

52 P. Kriedte, De herrschaft..., s. 64, 66; J. Maciejewski, Kościót $i$ duchowieństwo $w$ Świeciu nad Wista do poczatku XIV wieku [w:] Świecie i ziemia świecka w 800-lecie istnienia, red. M. Grzegorz, Bydgoszcz 1999, s. 68-69, przyp. 26.

53 A. Gut, Średniowieczna..., s. 111-112; S.M. Szacherska, Opactwo cysterskie w Szpetalu a misja pruska, Warszawa 1960, s. 37-3, przyp. 112; s. 44, przyp. 168; s. 50 , przyp. 200 . 
Ponadto A. Gut, podobnie jak wcześniej W. Łęga, ze względu na imię omawianego duchownego przypisuje mu słowiańskie pochodzenie. Badaczka w dodatku przypuszcza, że Wacław/Unisław wywodził się z rodziny określanej w literaturze jako dziedzice Lublewa ${ }^{54}$. Sytuację taką mogłyby potwierdzać wnioski Józefa Szymańskiego o powiązaniach kanoników z możnymi - na przykładzie Małopolski ${ }^{55}$. Przedstawiciele wspomnianej rodziny już od 1227 r. byli notowani w otoczeniu Świętopełka, także jako jego urzędnicy, należeli więc zapewne do jego zaufanych ludzi. Jeden z nich, sędzia gdański Andrzej, wzmiankowany po raz pierwszy w 1261 r., pełnił tę funkcję także na dworze Warcisława II. Brat Andrzeja natomiast, również Unisław, był u tego księcia podkomorzym gdańskim. Jak już wcześniej zaznaczono, braci można odnaleźć m.in. w tych dwóch omawianych dokumentach z 1268 r., a więc obok kleryka Wacława/Unisława. Owi dostojnicy kontynuowali swoje kariery również za czasów Mściwoja II, pojawiając się u jego boku już w 1270-1271 r., a więc być może jeszcze $\mathrm{w}$ trakcie wojny domowej. Według badaczy zagadnienia świadczyłoby to o tym, że Andrzej i Unisław poparli zmianę władzy, choć - jak sądzi B. Śliwiński - dopiero wtedy, gdy klęska Warcisława II okazała się przesądzona ${ }^{56}$. W przeciwieństwie do nich duchowny Wacław/Unisław już nie występuje w źródłach z czasów Mściwoja II. Mogłoby to oznaczać, że nie zgodził się na współpracę z nowym władca, co z kolei podawałoby w wątpliwość jego przynależność do rodziny z Lublewa. Mógł oczywiście postapić inaczej jak jego krewni. Niewykluczone również, że brak wzmianki o tym duchownym wynikał z przyczyn naturalnych $-\mathrm{z}$ powodu jego starości (występował w źródłach już od 1247 lub 1248 r.) lub nawet śmierci, która można by datować przed 1273 lub $1274 \mathrm{r}$. Wtedy bowiem u boku Mściwoja II pojawiają się pierwsi duchowni gdańscy, wśród których Wacława/Unisława brakuje ${ }^{57}$. Wniosek ten umacniałby także przykład kapelana gdańskiego Hermana, który również, m.in. ze względu na pojawienie się już 1247 r., nie

54 W. Łęga, Spoteczeństwo..., s. 61-62; A. Gut, Średniowieczna..., s. 116.

55 J. Szymański, Kanonikat świecki..., s. 82-88, 95-99.

56 Urzędnicy Pomorza Wschodniego do 1309 r. Spisy, oprac. B. Śliwiński, Ossolineum 1989, s. 34, 36-38; B. Śliwiński, Rola rycerstwa gdańskiego w okresie wojny domowej na Pomorzu Gdańskim w latach 1269-1272, ZH 1986, t. 51, z. 2, s. 12-14; idem, Andrzej (zm. 1296) [w:] SBPN, t. 1, s. 29-30.

$57 \mathrm{P}, \mathrm{nr} 258$. 
był przez badaczy utożsamiany ze znanym z lat 70 . kapelanem świeckim ${ }^{58}$. W opisanej sytuacji dałoby się utrzymać pokrewieństwo Wacława/Unisława ze wspomnianymi dostojnikami.

Kolejnym duchownym, którego można zaliczyć do otoczenia Warcisława II, był Godfryd. Po raz pierwszy wystapił w formule kancelaryjnej konfirmacji dóbr bukowskich jako notariusz książęcy (,notarius noster”), którego ręką został spisany powyższy dokument ${ }^{59}$. Funkcja ta w autentycznych źródłach wschodniopomorskich pojawiła się wcześniej jedynie w $1227 \mathrm{r}$. w odniesieniu do duchownego Jana. Jak jednak wskazała A. Gut, nawet gdyby trzy z pięciu dokumentów Warcisława II były sporządzone przez jego pisarzy (czyli dwa dokumenty dla Lubeki i układ z zakonem krzyżackim) ${ }^{60}$, nie może to bezwzględnie świadczyć o działaniu już na dworze księcia Warcisława II w pełni rozwiniętej kancelarii, która jest widoczna dopiero za późniejszych rządów Mściwoja II. W tej ostatniej jednak Godfryd także by działał, jak twierdzi badaczka, która jak dotąd najlepiej opracowała karierę tego duchownego. Mógł on być bowiem identyczny z osoba o tym imieniu występująca przy nowym władcy w latach 1276-1277. Być może dalej pełniłby swoje obowiązki notariusza-pisarza, na co wskazywałoby takie właśnie tłumaczenie terminu clericus, z którym występuje na powyższych dokumentach. Ponadto, podobnie jak wcześniej wskazywał K. Jasiński, z dużym prawdopodobieństwem Gotfryd należałby do gdańskiej grupy kanonickiej. Tym samym byłby jej jedynym przedstawicielem wśród członków personelu kancelaryjnego Mściwoja II. Pozostali notariusze przeszliby natomiast ze Świecia, choć A. Gut hipotetycznie wnioskuje o pierwotnych związkach z Gdańskiem również dwóch innych duchownych: notariusza Jakuba (1277) i tłumacza Andrzeja (1275-1293). Na podstawie imienia sugeruje pochodzenie Godfryda $z$ duchowieństwa niemieckiego ${ }^{61}$.

W dokumencie dla klasztoru w Bukowie z 1268 r. bezpośrednio za kapelanami grodowymi wystapił Luder (Ludger), określony jako

58 A. Gut, Średniowieczna..., s. 104, 112-114.

59 P, nr 235 (,per manus notarii nostri Godefridi”).

$60 \mathrm{P}, \mathrm{nr} 220,222,232$.

61 P, nr 281, 287, 288 (wg indeksu); K. Jasiński, Z problematyki..., s. 44-45; A. Gut, Średniowieczna..., s. 103-104, 109-121. Co do wymienionych dwóch duchownych, notariusz Andrzej ze względów chronologicznych raczej nie pełnił posługi za czasów Warcisława II. Bardziej prawdopodobne byłoby to w wypadku Jakuba. Brak jednak na to dowodów, zob. niżej o kapelanie Janie. 
kapłan kościoła św. Katarzyny w mieście Gdańsku ${ }^{62}$. Co istotne dla dalszych rozważań, według K. Jasińskiego świątynia ta była kościołem patronalnym książąt gdańskich, którzy mogli więc tam powoływać duchownych za zgodą biskupa ${ }^{63}$.

Postać Ludera doczekała się szczegółowych badań przeprowadzonych przez K. Jasińskiego i A. Gut. Na ich ustaleniach będzie oparty poniższy wywód, w którym jednocześnie zostanie podjęta próba uzupełnienia wniosków tych badaczy. Luder jako kapłan kościoła św. Katarzyny w Gdańsku wystapił także w dokumencie z 1263 r., z którego pochodzi pierwsza informacja o kościele św. Katarzyny, służącym mieszkańcom istniejącego przy grodzie gdańskim miasta na prawie lubeckim ${ }^{64}$. Według K. Jasińskiego, pomimo określenia Ludera tylko kapłanem, już w 1263 r. pełniłby funkcję plebana w tymże kościele, ale raczej nie pierwszego w dziejach tej świątyni. $\mathrm{Z}$ takim tytułem bowiem, choć ogólnie w odniesieniu do Gdańska, został odnotowany w $1273 \mathrm{r}$. Ten sam wniosek można więc odnieść także do omawianego dokumentu z 1268 r. W 1277 r. Luder wystapił zaś dwukrotnie bez określenia terytorialnego ${ }^{65}$.

Kazimierz Jasiński przypuszczał także, że Luder objął godność kapłana u św. Katarzyny z nadania księcia Świętopełka, gdyż władcy chcieli zachować swoje wpływy także wśród mieszczan, z którymi duchowny ten miałby liczne kontakty ${ }^{66}$. Warto zwrócić uwagę, że również Warcisław II starał się utrzymywać dobre stosunki z gdańskim miastem oraz Lubeka, o czym świadczą dwa przywileje wystawione dla kupców z tego ośrodka ${ }^{67}$. Być może wynikało

62 P, nr 235 („Luderus sacerdos de sancta Catharina in civitate Gedanck”). Imię tego duchownego pojawia się w różnych wariantach, wymienia je A. Gut, według której w rzeczywistości mogło ono brzmieć „Liudiger”, zob. eadem, Autentyczność dokumentu Świętopetka II, księcia wschodniopomorskiego, dla klasztoru cystersów w Oliwie $z 25$ listopada 1263 roku [w:] A Pomerania ad ultimas terras..., s. 233. W niniejszym artykule pozostawiono formę występującą najczęściej w źródłach i utrwalona w historiografii.

63 K. Jasiński, Gdańsk w okresie samodzielności politycznej Pomorza Gdańskiego [w:] Historia Gdańska, t. 1, red. E. Cieślak, Gdańsk 1978, s. 281. Może na to wskazywać choćby fakt, że Świętopełk musiał uzyskać zgodę biskupa kujawskiego na przekazanie kościoła św. Mikołaja dominikanom w 1227 r., zob. P, nr 34.

$64 \mathrm{P}, \mathrm{nr} 202$. O autentyczności tego dokumentu zob. A. Gut, Autentyczność dokumentu..., s. 230-235.

65 P, nr 257, 287, 288; K. Jasiński, Luder (I pot. XIII w. - po 1285)..., s. 90-91.

66 K. Jasiński, Luder (I pot. XIII w. - po 1285)..., s. 90.

$67 \mathrm{P}, \mathrm{nr} 220$ (Gdańsk, 10 maja 1267 r.) i omawiany P, nr 232; opinię taką wyraził K. Jasiński, Gdańsk w okresie samodzielności..., s. 278-279; zob. także 
to z potrzeb politycznych i było oznaką poszukiwania przez księcia gdańskiego sojusznika w sporach z przeciwnikami zewnętrznymi i wewnętrznymi. W tym świetle szczególnie istotna wydaje się obecność Ludera w omawianym dokumencie dla klasztoru bukowskiego z 1268 r., położonego w ziemi sławieńskiej, o którą toczył się spór z księciem zachodniopomorskim Barnimem I. Luder mógł więc znaleźć się tutaj w związku z obowiązkami pełnionymi w Gdańsku, gdzie byłby - hipotetycznie - pośrednikiem lub współpracownikiem Warcisława II w relacjach z mieszczaństwem, co dla późniejszego okresu rządów Mściwoja II sugerowali K. Jasiński i A. Gut. Jednocześnie byłby to przykład wpływu środowiska gdańskich mieszczan na pierwszego z władców, jak przypuszczał K. Jasiński, opierając się na wspomnianych dwóch przywilejach dla lubeczan. Wpływ ten uległ jednak jego zdaniem zdecydowanemu osłabieniu za rządów Mściwoja II, który poddał represjom miasto gdańskie w odwecie za poparcie agresji brandenburskej w latach 1271-1272, i do końca swych rządów ich nie odwołał ${ }^{68}$.

Zarysowany obraz wzajemnych stosunków Warcisława II z mieszczanami gdańskimi mógłby jednak zostać osłabiony przez dalsze losy Ludera. Pomimo bowiem represji Mściwoja II wobec mieszczan, jak wskazali historycy, duchowny ten dalej pełnił swoje funkcje, a nawet, najwcześniej w 1279 r., został także pierwszym i jedynym działajacym na dworze książąt wschodniopomorskich kanclerzem. Urząd ten pełnił najpewniej do 1285 r., kiedy po raz ostatni wystapił w źródłach. W opinii B. Śliwińskiego, jak wspomniano, ów pleban miał spośród gdańskich duchownych w otoczeniu Mściwoja II największe znaczenie ${ }^{69}$. Zastanawia, co było tego powodem. Według B. Śliwińskiego Luder cieszył się przychylnością władcy prawdopodobnie dlatego, że hipotetycznie znalazł się w grupie kleru, która nie poparła zajęcia miasta przez margrabiego

W. Długokęcki, Hanza a Gdańsk na przełomie XIII i XIV wieku [w:] „Rzeź Gdańska” $z 1308$ roku w świetle najnowszych badań. Materiały z sesji naukowej 12-13 listopada 2008 roku, red. B. Śliwiński, Gdańsk 2009, s. 27-38 (szczególnie s. 30), gdzie też starsza literatura; zob. także J. Sikorski, Z przeszłości „prawa brzegowego” $w$ Polsce, „Przegląd Zachodni” 1951, R. 6, nr 1-2, s. 77-81; M. Szuba, Stosunki zewnętrzne..., s. 208-209.

68 K. Jasiński, Gdańsk w okresie samodzielności politycznej..., s. 278-279, 298-299; idem, Chronologia..., cz. II, s. 65-66; 75-77; idem, Luder (I pot. XIII w. - po 1285 r.)..., s. 90-91; A. Gut, Urzqd..., s. 55; eadem, Średniowieczna..., s. 106-109, 116.

69 A. Gut, Urzad..., s. 55-56; eadem, Średniowieczna..., s. 108; B. Śliwiński, Herman..., s. 191-192. 
Konrada $^{70}$. Wyjaśnienie to wydaje się logiczne - wynika z przyjętej przez historyka argumentacji i metody badawczej opartej na analizie otoczenia władców. Wciąż jednak rzuca się w oczy rozdźwięk między postawą mieszczan i plebana kościoła św. Katarzyny. Pojawia się także pytanie, czy te różnice miały miejsce już za czasów Warcisława II. Nie widać ich jednak w źródłach. Jak wspomniano, od 1263 r. Luder występował w dokumentach odnoszacych się do miasta i obok mieszczan. Dotyczy to także okresu rządów księcia Warcisława, który starał się utrzymywać dobre relacje z mieszczaństwem Gdańska (być może i Słupska) oraz Lubeka, na co mogłyby wskazywać jego dwa przywileje dla tej ostatniej ${ }^{71}$. Być może, że postawa Ludera podczas akcji Brandenburczyków wynikała z tego, że był duchownym mianowanym przez księcia, jeśli przyjmie się zdanie K. Jasińskiego. Należałby więc do zaufanych władcy i realizował jego politykę - zarówno Świętopełka, jak i Warcisław II czy Mściwoja II - skoro każdy z nich pozostawił Ludera na stanowisku. W tym kontekście wydaje się zrozumiały sprzeciw Ludera wobec zajęcia Gdańska przez margrabiego Konrada, które było niezgodne z interesami władcy, ale z kolei zgodne z dążeniami mieszczan- Niemniej warto dodać, że fakt objęcia przez Ludera funkcji kanclerza nie musi przeczyć jego wcześniejszej współpracy z Warcisławem II. Mściwoj II nawiązywał bowiem współpracę z dawnymi stronnikami swego brata, co widać na przykładzie rycerstwa, choć dopiero w latach 80 . XIII w. ${ }^{72}$

Również pleban kościoła św. Katarzyny nie musiał być formalnie związany z dworami książąt gdańskich, jak wskazała A. Gut, a więc dotyczyłoby to także i okresu rządów Warcisława II. Powołanie Ludera na kanclerza, jak przypuszcza badaczka, mogło także wynikać nie z wewnętrznych potrzeb, ale z wymogów prowadzonego na przełomie lat 70. i 80. XIII w. procesu zjednoczenia politycznego Pomorza Gdańskiego z Wielkopolska, gdzie urząd kanclerza funkcjonował w każdej z dwóch dzielnic (kalisko-gnieźnieńskiej

70 B. Śliwiński, Mściwoj II..., s. 177.

71 Zob. prz. 67.

72 Zob. B. Śliwiński, Rola polityczna możnowtadztwa..., s. 82-83, 161-162; idem, Mściwoj II..., s. 149, przyp. 3, s. 269, 298. Jako przykład wskazuje się tutaj wojewodę białogardzkiego Dobiegniewa z lat 1283-1287, uznawanego przez powyższego badacza za syna palatyna gdańskiego o tym samym imieniu z czasów Warcisława II. Podsumowanie dyskusji na temat Dobiegniewów zob. M. Szuba, Możni..., s. $130-132$. 
i poznańskiej). Świadczyłaby o tym korelacja dat, pod którymi Luder był wzmiankowany jako kanclerz, z wydarzeniami zwiazanymi z tym procesem, jak układ w Kępnie z 1282 r. czy bunt Dziwana z 1285 r., oraz brak funkcjonowania tego właśnie urzędu po tej dacie, choć mogło to wynikać z naturalnej śmierci Ludera ${ }^{73}$. Wskazane przesłanki pozwalają na sformułowanie przypuszczenia o pewnej niezależności lub znaczących umiejętnościach politycznych duchownego. Luder mógł być także po prostu niezbędny Mściwojowi II, ze względu na swoje wykształcenie i doświadczenie. Można założyć, że również za czasów Warcisława II Luder nie należał formalnie do dworu władcy (na co zresztą nie ma dowodów), w przeciwieństwie do kapelanów księcia. Pomimo tego jednak służył księciu ze wskazanych wyżej powodów.

Kazimierz Jasiński uznawał także za możliwą przynależność Ludera do gdańskiej grupy kanonickiej, gdyż w 1277 r. dwukrotnie został nazwany książęcym kapelanem. Sprzeciwiła się temu A. Gut i P. Samól. Badaczka wskazała, że ze względu na wystawienie świadczących o tym dokumentów na dworze biskupa kujawskiego termin kapelana mógł się odnosić do wszystkich duchownych towarzyszących wtedy Mściwojowi II. Współpraca Ludera z Mściwojem II przed 1279 r. miałaby jednak miejsce, lecz nie byłaby sformalizowana pełnieniem określonej i związanej z tym funkcji. Paweł Samól stwierdził zaś, że pozycja Ludera na liście świadków byłaby przejawem wspomnianego przejęcia znaczenia kościoła grodowego przez kościół św. Katarzyny ${ }^{74}$.

Niegdyś za duchownego uznawano także tłumacza Henryka, występującego wśród świadków traktatu pokojowego z zakonem krzyżackim, wystawionego w Świeciu 1 sierpnia 1267 r. ${ }^{75}$ Pomimo swej funkcji - zdaniem badaczy - najprawdopodobniej był jednak osobą świecka, ponieważ został wymieniony pomiędzy nimi, a nie wśród umieszczonych wyżej w testacji duchownych. Warto jednak zwrócić na niego uwagę w kontekście działalności personelu kancelaryjnego, także w sytuacji upadku Warcisława II. Ze względu

73 A. Gut, Urzad kanclerza..., s. 55-59; eadem, Średniowieczna..., s. 108.

74 K. Jasiński, Luder (I pot. XIII w. - po 1285 r.)..., s. 90; E. Rymar, Udziat rodu Wedlów w ekspansji margrabiów brandenburskich na Pomorze Środkowe $i$ Wschodnie w latach 1269-1313 [w:] Pomorze stowiańskie..., s. 46-47; A. Gut, Urzad kanclerza..., s. 55; eadem, Średniowieczna..., s. 106-108; P. Samól, Kościót grodowy..., s. 180-181.

$75 \mathrm{P}, \mathrm{nr} 222$. 
na miejsce występowania i późniejsze możliwe pojawienie się Henryka w liście Mściwoja II do margrabiów brandenburskich w 1271 r., uznawano go za członka otoczenia tego właśnie księcia. Jednak niewykluczone, na co wskazał B. Śliwiński, iż Henryk działał również na dworze Warcisława II w Gdańsku i tam zastał go w momencie zdobycia grodu Mściwoj $\mathrm{II}^{76}$.

W przywileju Warcisława II dla klasztoru w Bukowie jako świadek został wymieniony także „Michael prepositus de Saulin”. W wypadku tego duchownego dyskusyjna jest zarówno jego funkcja, jak i miejsce posługi. Pierwszy wydawca dokumentu z tą wzmianka, Friedrich Dreger, utożsamił Saulin z miejscowością Salino nad jeziorem o tej samej nazwie ${ }^{77}$. Wątpliwości zgłosił jednak Ludwig Quandt, który wskazał co prawda, że miejscowość ta była siedziba parafii („Pffardorf”), to jednak nie prepozytury w przyjętym przez niego rozumieniu („Probstei”), czyli związanej z klasztorami lub kapitułami ${ }^{78}$. Dlatego też zapis miejscowości uznał za pomyłkę, tym bardziej że źródła bukowskie zawierały jego zdaniem wiele błędów. Za poprawną uznał natomiast Strzelno (Strelin), gdzie mieściła się prepozytura norbertanek ${ }^{79}$. Kolejny wydawca dokumentu, M. Perlbach, również umieszczał Michała w Salinie, a jego tytuł proponował utożsamiać z plebanem, gdyż w powyższej miejscowości rzeczywiście nigdy nie istniała prepozytura w rozumieniu L. Quandta ${ }^{80}$. Powyższą lokalizację utrzymał Franz Schultz. Ponadto wskazał na możliwą odrębność administracyjną oraz odosobnienie Salina i okolicy, które uzasadniałaby obecność prepozyta. Pod tym pojęciem rozumiał bowiem duchownego o szerszych kompetencjach i obszarze działania ${ }^{81}$. Później lokalizację Michała w Salinie przyjęła większość badaczy. Miejscowość tę umieszcza się w granicach

76 P, nr 250; B. Śliwiński, O kasztelanie..., s. 121; A. Gut, Średniowieczna..., s. $105-106$.

77 Codex Pomeraniae vicinarumque terrarum diplomaticus..., Bd. 1, hrsg. v. F. Dreger, Berlin 1768, s. 539, przyp. c.

78 Tak tłumaczono wyraz prepostitura we współczesnych słownikach, a prepositus jako Probst, zob. L. Diefenbach, Mittellateinisch-hochdeutsch-bohmisches Worterbuch nach einer Handschrift vom Jahre 1470..., Frankfurt a. M. 1846, s. 221; idem, Glossarium Latino-Germanicum mediae et infimae aetatis, Francofurti ad Moenum 1857, s. 455.

79 L. Quandt, Ostpommern, seine Fürsten, fürstlichen Landestheilungen und Distrikte, BS AF 1856, Jg. 16, H. 1, s. 143, przyp. 123.

80 P, s. 191, przyp. 3.

81 F. Schultz, Geschichte des Kreises Lauenburg in Pommern, Lauenburg 1912, s. 427. 
kasztelanii białogardzkiej. Wskazuje się także, biorąc pod uwagę stosunki panujące za czasów krzyżackich, że Salino już wcześniej mogło stanowić ośrodek jednostki administracyjnej, czy to niższego rzędu, jak okręg sądowy, czy nawet osobnej kasztelanii ${ }^{82}$.

Zarówno przytoczona interpretacja, jak i lokalizacja pozostaja jednak problematyczne, ponieważ pytanie o posługę w Salinie duchownego o wspomnianym tytule pozostaje nierozstrzygnięte. W dodatku termin „prepozyt” jest wieloznaczny i odnosi się do różnych instytucji kościelnych. Na początku należy raczej odrzucić najczęściej spotykane skojarzenie tego tytułu z członkiem kapituły katedralnej lub kolegiackiej, co częściowo uczynił L. Quandt ${ }^{83}$, gdyż tego typu instytucje najprawdopodobniej jeszcze wtedy na Pomorzu Wschodnim nie istniały ${ }^{84}$. Podobnie brak śladów istnienia prepozytury zwiąanej z archidiakonatem pomorskim biskupstwa włocławskiego, choć P. Kriedte uważał, że być może wykształciła się ona z grup kanonickich w Gdańsku i Świeciu i wiązał ja z inną prepozytura św. Wojciecha „Pod Dębem”, obecnie w dzielnicy Gdańska św. Wojciech. Wniosek ten wynikał jednak z założenia, iż grupy te były powiazane $\mathrm{z}$ biskupem, co jak opisano, trzeba uznać raczej za watpliwe ${ }^{85}$. Miejscowy archidiakon, przypuszczalnie rezydujacy w Gdańsku, prawdopodobnie należał do kapituły włocławskiej ${ }^{86}$, co starsi badacze uznawali za typowe do XV w. ${ }^{87}$ Natomiast prepozytura w św. Wojciechu należała do benedyktynów, o czym niżej. Możliwe, iż tytuł Michała oznaczał miejscowego proboszcza, tak jak proponował M. Perlbach. Wskazano bowiem, że w XIV w. na ziemiach polskich proboszcza nazywano w różny sposób: plebanus,

82 Już F. Dreger wyznaczał tu osobny okręg grodowy, zob. Codex..., s. 539, przyp. C; K. Bruski, Rycerstwo ziemi lęborskiej w czasach średniowiecza, „Biuletyn Lęborskiego Bractwa Historycznego i Muzeum w Lęborku” (dalej: Biuletyn) 1997, nr 4 , s. 23.

83 Stownik taciny średniowiecznej w Polsce, t. 7, z. 7 (58), Kraków 1997, szp. 999-1000; J. Szymański, Z zagadnień vitae canonicae..., s. 145.

84 K. Jasiński, $Z$ problematyki..., s. 38-46. O początkach kolegiat w Polsce i występujących w nich prepozytach zob. J. Szymański, Biskupstwa..., s. 205-216; J. Dobosz, Monarchia i możni wobec Kościoła w Polsce do poczatku XIII wieku, Poznań 2002, s. 427-433.

85 P. Kriedte, Die Herrschaft..., s. 58-66.

86 K. Jasiński, Z problematyki..., s. 41-42 (w odniesieniu do kolegiaty); idem, Gdańsk w okresie samodzielności politycznej..., s. 282. O archidiakonacie pomorskim zob. J. Spors, Podziaty..., s. 46-52; M. Smoliński, Relacje..., s. 66.

87 O organizacji archidiakonalnej zob. J. Szymański, Biskupstwa..., 222-229; idem, Kanonicy..., s. 73-74; J. Dobosz, Monarchia..., s. 430-431. 
parrochianus, capellanus, rector ecclesiae, ale także praepositus ${ }^{88}$, choć ten ostatni został użyty w stosunku do proboszcza dopiero w XV w. ${ }^{89}$ Tytuł prepozyta oznacza również zarządcę, administratora, co wobec domniemanej odrębności ziemi salińskiej mogłoby potwierdzać teorię F. Schultza. Na podstawie wzmianek źródłowych dotyczacych Salina godność miejscowego prepozyta można by odnieść do tytułu głównego duchownego szpitalnego lub obsługujacego należąca do leprozorium i przeznaczoną dla chorych kaplicę ${ }^{90}$. W źródłach XIV-wiecznych i późniejszych są bowiem widoczne związki Salina ze szpitalem św. Ducha w Gdańsku. Od 1344 r. wieś Salino, miejscowa parafia i pobliskie jezioro należały do tej instytucji. Szpitalny proboszcz był także proboszczem w Salinie, o czym wzmiankowano już w $1346 \mathrm{r} .{ }^{91} \mathrm{~W}$ dodatku tytuł prepozyta oznaczałby zarówno funkcję szpitalna, jak i patronat nad parafią salińska. W tym drugim sensie określenia prepozytury użyto $\mathrm{w}$ dokumencie margrabiów brandenburskich z 2 października 1311 r., w którym przyznali oni norbertanom z Białobuka i norbertankom ze Słupska prawo patronatu nad cała ziemią słupska ${ }^{92}$. Na podstawie powyższych wzmianek autor niniejszego artykułu zasugerował w innej pracy, że już w XIII w. istniały związki między parafia w Salinie a gdańskimi duchownymi ${ }^{93}$. Choć związki te nie są całkowicie wykluczone, to należy wspomnieć, że brakuje dowodów na istnienie w Gdańsku w latach 60. XIII w. (i w ogóle przed 1308 r., za czasów niezależnego księstwa wschodniopomorskiego) szpitala, pomimo że nieliczni badacze za tym się opowiadali ${ }^{44}$. Brak dowodów na związki własnościowe szpitala św. Ducha w Gdańsku i Salina osłabia interpretację tytułu

88 W. Karasiewicz, E. Piszcz, Episkopat, duchowieństwo i duszpasterstwo [w:] Historia Kościoła w Polsce..., t. 1, cz. 1, red. B. Kumor, Z. Obertyński, PoznańWarszawa 1974, s. 239.

89 E. Wiśniowski, Rozwój organizacji parafialnej w Polsce do czasów reformacji [w:] Kościót w Polsce..., t. 1, s. 282.

90 M. Słoń, Szpitale średniowiecznego Wrocławia, Warszawa 2000, s. 80-86; M. Sumowski, Prepozyci toruńskiego szpitala i kościoła św. Jerzego w średniowieczu, KMW 2012, nr 2 (276), s. 350-351.

91 PrU IV, nr 244 (,herr Friczko probist zu dem Heilege Geiste zu Danczk und pherrer zu Saulin").

92 PU, Bd. 5/1, nr 2682 [,Damus etiam (...) praeposituram per totam terram Stolp"]; B. Popielas-Szultka, Lokacja miasta Stupska na prawie lubeckim przez księcia Świętopełka II, „Słupskie Studia Humanistyczne” 1988, nr 9a (wyd. 1990), s. 19.

$93 \quad$ M. Szuba, Możni..., s. 139-140.

94 Ibidem, s. 139-140, gdzie w przyp. 40 źródła i dalsza literatura dot. szpitala św. Ducha i jego związków z Salinem. 
plebana salińskiego w odniesieniu do 1268 r., jednak odpowiednią dla okresu późniejszego, czyli po 1344 r.

Warto więc zwrócić uwagę na istniejące wówczas instytucje i inne, niż wyżej wspomniane, znaczenie urzędu prepozytury. Przysługiwało ono m.in. wyodrębnionej grupie kanonickiej obsługującej konkretna parafię. Użycie tytułu prepozyta służyło podkreśleniu kompetencji sądowych przełożonego tej grupy ${ }^{95}$. Istniała już wtedy na Pomorzu Wschodnim jedna taka grupa, mianowicie podgdańska prepozytura św. Wojciecha „Pod Dębem”, będąca filia klasztoru benedyktynów w Mogilnie. W źródłach była wzmiankowana od 1236 r., a istniała być może już w drugiej połowie XII w. ${ }^{96}$, chociaż nie ma innych, pewnych dowodów na istnienie takiej grupy w Salinie. Nie można jednak wykluczyć, że działała, choć należałoby ograniczyć czasowo jej istnienie do 1344 r. ${ }^{97}$ Można by ewentualnie wiązać plebana z Salina z pobliskim klasztorem cysterek w Żarnowcu, gdyż tytuł prepozyta nosił duchowny w tego typu zgromadzeniach. Pierwsza wzmianka o prepozycie żarnowieckim pochodzi z 5 marca 1283 r. - był nim Gerlach, wcześniej przeor i szafarz oliwski. Jednakże zdaniem Dariusza A. Dekańskiego posługiwał on w Żarnowcu, nie w Salinie. Warto też dodać, że Gerlach został tu nazwany wprost ,preposito monialium in Zarnowitz”, czyli prepozyt zakonny, posługujacy w samym klasztorze, a nie w innej świątyni czy parafii. Michał z Salina był natomiast nazwany tylko prepozytem. Nie ma też śladów na przynależność Salina do dóbr klasztoru w Żarnowcu ${ }^{98}$. Bardziej prawdopodobne byłoby wiązanie Michała z klasztorem norbertanek w Zukowie. Wreszcie tytuł Michała, a nawet miejsce jego posługi, mogły przetrwać w błędnej

95 J. Szymański, Poczatki prepozytur w diecezji krakowskiej, RTK 1962, t. 9, z. 1, s. 65-66; idem, $Z$ zagadnień vitae canonicae..., s. 149-150.

96 A. Czacharowski, Benedyktyńska prepozytura św. Wojciecha ad Quercum [w:] Venerabiles, Nobiles et Honesti. Studia z dziejów spoteczeństwa Polski średniowiecznej, red. A. Radzimiński, A. Supruniuk, J. Wroniszewski, Toruń 1997, s. 77-78; S. Kościelak, Benedyktyni [w:] Encyklopedia Gdańska, https://www.gedanopedia.pl/ gdansk/?title=BENEDYKTYNI (dostęp: 28.09.2020); M. Smoliński, Relacje..., s. 89-90.

97 J. Szymański, $Z$ zagadnień..., s. 149-150.

98 P, nr 357; D.A. Dekański, Badania prozopograficzne opactw cysterskich Pomorza Gdańskiego do 1309 r., zwłaszcza opactwa w Oliwie, NP 1994, t. 83, s. 266-267, 273-274, 276; Spisy członków konwentów..., s. 54, 56, 68; por. K. Dąbrowski, Rozwój wielkiej własności ziemskiej klasztoru cystersek w Żarnowcu, Gdańsk 1970, s. 59, prz. 278. Pracę tę poddało krytyce wielu badaczy. Ich opinie zebrała F. Sikora, Poczatki klasztoru cystersek $w$ Żarnowcu, ZH 1983, t. 43, z. 1-2, s. 7-28 (szczególnie s. 26-27). 
formie, w wyniku pomyłki pisarza lub kopisty, ponieważ podstawą wydania dokumentu jest powstała na początku XVII w. kopia wcześniejszej, XIV-wiecznej metryki klasztoru bukowskiego, która jednak zaginęła. Jak wskazują badacze, kopia ta zawiera liczne błędy, co najpewniej wynikało ze słabych umiejętności osoby, która ja przygotowywała ${ }^{99}$. Być może użycie tytułu prepozyta wobec Michała stanowi późniejszą reminiscencję funkcjonowania w ziemi salińskiej okręgu sądowego, choć nie ma pewności, czy istnienie tego okręgu można przesuwać do XIII w. ${ }^{100}$

Błąd lub zniekształcenie mogły także dotyczyć nazwy miejsca posługi. Raczej nie należy jej odnosić do Sławna i tamtejszego domu joannitów, którzy również posługiwali się tytułem prepo$z^{z y t a}{ }^{101}$. Występuje bowiem duża różnica między nazwą tego grodu (Sclawen w dokumecie bukowskim z 1265 r.) ${ }^{102}$ a Saulin. Również w pobliżu Salina nie było majątków joannickich ${ }^{103}$. Należy więc powrócić do propozycji zgłoszonej przez L. Quandta, według której Michał pochodziłby z klasztoru norbertanek w Strzelnie na Kujawach. Jednocześnie sprzeciwiał się wiązaniu Michała z Żukowem. $\mathrm{Z}$ tym twierdzeniem należy się raczej zgodzić, pomimo wzmianki o urzędzie tamtejszego prepozyta już w 1238 r. ${ }^{104}$ Współczesna nazwa

99 L. Quandt, Ostpommern..., H. 1, s. 143, przyp. 123; A. Gut, Dokumenty dla klasztoru cysterskiego w Bukowie Morskim do 1316 roku, ZH 2008, t. 73, z. 1, s. 97-98 (gdzie starsza literatura). W omawianej podstawie rękopiśmiennej również występuje forma „Michael prepositus de Saulyn”, zob. P nr, 235; Archiwum Państwowe w Szczecinie, Zbiór Samuela Gottlieba Loepera, sygn. 12/160, fol. 96. Należy ją jednak skonfrontować z odpisem Friedricha Dregera, podanym przez A. Gut, Dokumenty..., s. 98 przyp. 4.

100 Tytułu prepozyta używał także niższy urzędnik sądowy baliwatów w średniowiecznej Francji, zob. Du Cange, Glossarium mediae et infimae latinitatis, Niort 1883-1887, t. 6, za: http://ducange.enc.sorbonne.fr/PRAEPOSITI (dostęp: 10.04.2020). Kwestia istnienia kasztelanii w Salinie wymaga osobnych badań.

101 M. Smoliński, Kontakty joannitów z kanonikami regularnymi, premonstratensami i bożogrobcami w XII i XIII w. (przede wszystkim na terenach Czech, Moraw, Polski i Ślaska) ze szczególnym uwzględnieniem fundacji szpitalników kujawskich [w:] Krzyżowcy, kronikarze, dyplomaci, red. B. Śliwiński, Gdańsk-Koszalin 1997 („Gdańskie Studia z Dziejów Średniowiecza”, nr 4), s. 218-224. O historii domu w Sławnie i stosunkach joannitów z władcami pomorskimi do omawianego czasu zob. idem, Joannici $w$ polityce ksiażat polskich i pomorskich od połowy XII do pierwszego ćwierćwiecza XIV wieku, Gdańsk 2008, s. 69-88, 173-183, 202-217.

$102 \mathrm{P}, \mathrm{nr} 208$.

103 PU, Bd. I/1, nr 215; P, nr 63; M. Smoliński, Joannici..., s. 69-70.

104 P, nr 67; A. Czacharowski, Uposażenie i organizacja klasztoru norbertanek $w$ Żukowie od XIII do połowy XV wieku, RTNT 1963, R. 68, z. 2, s. 57. Pierwszy 
Żukowa (Suckowie, Sukaw) ${ }^{105}$, a także pierwotnego miejsca fundacji klasztoru: Stołpi, również zdają się zbyt mocno różnić od Saulyn, by te miejsca utożsamiać.

Kwestia związków z klasztorem w Strzelnie wymaga jednak więcej uwagi. Powstał on przed 1193 lub 1190 r., a pierwsza wzmianka o tamtejszym prepozycie pochodzi z $1225 \mathrm{r} .{ }^{106}$ Sa znane kontakty tej instytucji z Pomorzem Wschodnim i Sobiesławicami, po raz pierwszy w kontekście założenia zgromadzenia w Stołpi-Żukowie, dla którego prepozytura w Strzelnie stanowiłaby klasztor matke ${ }^{107}$. Pomorski konwent został ufundowany w 1212-1214 r. przez Mściwoja I i Zwinisławę. Badacze wskazuja, iż wydarzenie to miało kontekst polityczny związany z konfliktem między polskimi książętami, a znaczną rolę odgrywali w nim norbertanie. Warto zaznaczyć, że zdaniem historyków do powstania tego klasztoru miał się przyczynić Alard, opat św. Wincentego we Wrocławiu i wizytator konwentu w Strzelnie ${ }^{108}$. W takiej właśnie roli występuje przy potwierdzeniu dóbr klasztoru w Stołpi-Żukowie z datą $1224^{109}$. Alard pojawił się jeszcze w bulli papieskiej z 5 maja 1227 r. jako członek komisji kościelnej powołanej po najeździe Prusów z 1226 r., podczas którego zniszczono klasztory w Oliwie i Stołpi i zamordowano ich członków ${ }^{110}$. Wiadomo jeszcze o odszkodowaniu, które Świętopełk musiał wypłacić prepozytowi w Strzelnie za zniszczenie

znany z imienia prepozyt został wymieniony w 1316 r., zob. M. Smoliński, Klasztor i wieś Żukowo na przełomie XIII i XIV wieku [w:] Dzieje Żukowa..., s. 75.

$105 \mathrm{P}, \mathrm{nr} 67-1238$ r., 177 - 1259 r.

106 D. Karczewski, Dzieje klasztoru norbertanek $w$ Strzelnie do poczatku XVI wieku, Inowrocław 2001, s. 94-95, 237.

107 B. Śliwiński, Wieś Żukowo wedle najdawniejszych źródet pisanych [w:] Dzieje Żukowa, red. idem, s. 41-48; D. Karczewski, Dzieje..., s. 240-241. Ostatnio Rafał Kubicki nazwał klasztor w Żukowie prepozytura klasztoru w Strzelnie, zob. R. Kubicki, Monastycyzm na Pomorzu do poczatku XIX wieku [w:] 1050. rocznica Chrztu Polski, red. K. Lewalski, Gdańsk 2016, s. 139.

108 B. Śliwiński, Wieś Żukowo..., s. 41-48; idem, Okoliczności fundacji klasztoru norbertanek $w$ Żukowie pod Gdańskiem, „Annales Academiae Paedagogicae Cracoviensis. Studia Historica” 2007, t. 5, s. 19-35; M. Smoliński, Latyfundium klasztoru żukowskiego w średniowieczu. Próba periodyzacji stosunków gospodarczych, „Annales Academiae Paedagogicae Cracoviensis. Studia Historica” 2007, t. 5, s. 85; idem, Relacje..., s. 94-95 (w tych pozycjach starsza literatura na temat dziejów klasztoru w Stołpi-Żukowie).

109 P, nr 26; T. Hirsch, Das Kloster Zuckau im dreizehnten und vierzehnten Jahrhundert, „Der neuen Preussischen Provinzial Blatter” 1853, Bd. 3, s. 12.

110 P, nr 36; B. Śliwiński, Wieś Żukowo..., s. 51-55; M. Smoliński, Latyfundium..., s. 87-88. 
jego wsi podczas najazdu w 1238 r. Zdaniem B. Śliwińskiego książę wtedy nie zważał, czyje majątki niszczy ${ }^{111}$. W późniejszym okresie brak jednak bezpośrednich dowodów na kontakty między oboma zgromadzeniami norbertanek, niemniej nie można ich wykluczać, a nawet wydają się prawdopodobne, skoro pierwsza obsada klasztoru w Stołpi-Z̈ukowie pochodziła ze Strzelna, nawet pomimo całkowitego zniszczenia pomorskiego konwentu w $1226 \mathrm{r}$. Badacze podkreślaja również bliskie stosunki Sobiesławiców z tamtejszymi norbertankami, do których przystępowały także członkinie dynastii ${ }^{112}$. Świętopełk, pomimo chwilowego ochłodzenia relacji spowodowanego konfliktem z cystersami oliwskimi o dobra w Kępie Oksywskiej, do końca życia utrzymał dobre stosunki z norbertankami, o czym może świadczyć przywilej z 1259 r., w którym przyznał mniszkom znaczace nadania ${ }^{113}$.

Niestety, w wypadku Warcisława II nie zachowały się żadne wzmianki o jego kontaktach z konwentem w Żukowie. W przeciwieństwie do relacji z cystersami w Oliwie czy Bukowie. Tym pierwszym już w 1266 r. książę gdański nadał fragment Wisły (prawdopodobnie przewłokę) między jej dopływami: Ganską i Barszycą (Warsznica) w zamian za obietnicę pochówku w klasztorze ${ }^{114}$. Pomimo tego nie jest wykluczona wizyta prepozyta strzeleńskiego na dworze księcia gdańskiego, zakładając, że chodziłoby o Michała. Wizyta taka miałaby związek ze sprawami klasztoru żukowskiego lub tylko jego wizytacja

Wskazano na jeszcze jedną możliwość identyfikacji, według której wymieniony w omawianym dokumencie „Saulyn” można utożsamiać ze „Slona” z dokumentów Świętopełka dla wspomnianej

111 B. Śliwiński, Pogranicze kujawsko-pomorskie w XII-XIII w. Z dziejów Bydgoskiego $i$ Wyszogrodzkiego w latach 1113-1296, Warszawa-Poznań 1989, s. 131-134; D. Karczewski, Dzieje..., s. 145-146; M. Smoliński, Relacje..., s. 90, 102.

112 B. Śliwiński, Wieś Żukowo..., s. 56-59; M. Smoliński, Relacje..., s. 81-82; 127-130, gdzie starsza literatura.

113 P, nr 177; T. Rembalski, Dzieje osadnictwa na terenie wspótczesnych gmin Gdynia i Kosakowo od XIII do XV wieku, Gdynia 2006, s. 50-59, gdzie starsza literatura na temat sporu o Kępę Oksywska; M. Smoliński, Świętopełk gdański..., s. $166-169$.

114 P, nr 217. Zdaniem badaczy chodziło tu o przewłokę do połowu ryb, zob. E. Keyser, Olivaer Studien, I, ZWG 1926, H. 66, s. 85; idem, Olivaer Studien, II, ZWG 1928, H. 68, s. 20; W. Łęga, Obraz gospodarczy Pomorza Gdańskiego w XII i XIII wieku, Poznań 1949, s. 13; K. Dąbrowski, Opactwo..., s. 70 (tam starsza literatura); J. Powierski, Ksztattowanie sie granicy pomorsko-pruskiej od XII do poczatku XIV wieku (część II) [w:] idem, Prussica. Artykuty wybrane z lat 1965-1995, t. 2, Malbork 2005, s. 75-76, przyp. 86. 
benedyktyńskiej prepozytury św. Wojciecha „Pod Dębem” z 1236 r. ${ }^{115}$ Józef Płocha hipotetycznie lokalizował owo „Slona” w ziemi kołobrzeskiej ${ }^{116}$, co jednak należy odrzucić, gdyż nie ma śladów, by książęta gdańscy kiedykolwiek tam panowali. Ziemia ta należała do książąt zachodniopomorskich ${ }^{117}$. Bardziej uzasadniona jest uwzględniona przez Józefa Płocha teoria Maksa Perlbacha oraz Mieczysława Gębarowicza, którzy utożsamiali „Slona”, choć nie mieli tu całkowitej pewności, ze Slonnen (Słonem) w powiecie kościerskim ${ }^{118}$. Na większe prawdopodobieństwo tej lokalizacji wskazuje mniejsza odległość od prepozytury św. Wojciecha. Podobnie bliskość terytorialna w stosunku do Gdańska, gdzie wystawiono dokument z 1268 r., przemawiałaby za Słonem jako miejscem posługi Michała. Tym bardziej że zgodnie z przywilejem z 1236 r. stał tam kościól. Tłumaczyłoby to tytuł Michała na równi z powiązaniem z prepozyturą św. Wojciecha. Co więcej, tamtejsi duchowni pełnili ważne funkcje, jak w wypadku Piotra, archidiakona pomorskiego w latach 1288-1290 i oficjała z 1289 r. ${ }^{119}$, chociaż służba u biskupa kujawskiego, nadajacego powyższe godności, osłabiałaby z podanych względów możliwość współpracy z Sobiesławicami.

Natomiast gdyby pozostać przy założeniu o umieszczeniu Michała w Salinie, jego obecność w dokumencie z 9 października 1268 r. mogła mieć kontekst polityczny. Należy więc przyjrzeć się dziejom dzielnicy białogardzkiej w tym czasie. Kazimierz Jasiński wskazał, że jej przynależność po śmierci Świętopełka w 1266 r. jest problematyczna, zależała bowiem od tego, czy wciąż przebywał w niej Racibor. Badacz uważał, że na dokumencie z 9 października 1268 r. pojawiają się przedstawiciele ziemi białogardzkiej, co mogłoby świadczyć

115 P, nr. 54-56. Powyższą uwagę zgłosił prof. Klemens Bruski podczas dyskusji nad tekstem referatu, na podstawie którego powstał niniejszy tekst, przeprowadzonej 13 czerwca 2019 r. Za ten cenny głos autor serdecznie Panu Profesorowi dziękuje.

116 J. Płocha, Najdawniejsze dzieje opactwa benedyktynów w Mogilnie, Wrocław 1969, s. 229-230.

117 J. Spors, Dzieje polityczne ziem stawieńskiej, stupskiej i białogardzkiej XII-XIVw., Poznań 1973, s. 54-65, 180.

118 P, s. 46, przyp. 1; M. Gębarowicz, Mogilno-Ptock-Czerwińsk. Studia nad organizacja Kościoła na Mazowszu w XI i XII w. [w:] Prace historyczne w 30-lecie działalności profesorskiej St. Zakrzewskiego, Lwów 1934, s. 160. Wyjaśnienie to przyją Cz. Deptuła, Krag kościelny płocki w połowie XII wieku, „Roczniki Humanistyczne" 1959 , t. 8, z. 2, s. 108.

119 P, nr 56; A. Czacharowski, Benedyktyńska prepozytura..., s. 77-78. Być może więc rację miał P. Kriedte o istnieniu tutaj prepozytury archidiakonalnej, zob. P. Kriedte, Die Herrschaft..., s. 65. 
o przejęciu tam władzy przez Warcisława II $^{120}$. Powołał się na zdanie M. Perlbacha, który umieszczał Michała oraz jeszcze jedną osobę, mianowicie Radzisława, w ziemi białogardzkiej. Twierdził, że wieś Glowitz, z której pochodził Radzisław, to znana z okresu krzyżackiego zaginiona wieś Glewicze nad jeziorem Łebsko ${ }^{121}$. Na ten sam argument źródłowy powołał się J. Spors ${ }^{122}$. Jego zdaniem obecność świadków Radzisława i Michała w dokumencie Warcisława II, choć też przez niego niewymienionych z imienia, mogłaby przemawiać za tym, że dzielnica białogardzka po śmierci Świętopełka w 1266 r. przeszła bezpośrednio pod władzę Warcisława II jako jego spadkobiercy. Wcześniej bowiem Racibor uznał zwierzchnictwo starszego brata i dziedziczne prawa jego potomków. Ewentualnie, według J. Sporsa, Racibor mógł występować jako współwłaściciel, także w czasach rządów swego bratanka ${ }^{123}$.

Kolejni badacze skupili się na jeszcze innym aspekcie. Jak bowiem wspomniano, przypuszczalnie na lata 60. XIII w. historycy datuja opuszczenie przez Racibora Pomorza i przekazanie przez niego dzielnicy białogardzkiej zakonowi krzyżackiemu. Nieliczni spośród nich uważaja, że doszło do tego za życia Świętopełka, czyli przed 1266 r., większość jednak wskazuje okres po tej dacie. Ostatnio B. Śliwiński zaproponował, że akt Racibora nastapił bezpośrednio po zgonie księcia gdańskiego, ale przed 1 sierpnia 1267 r., gdy Warcisław II zawarł układ pokojowy z Krzyżakami. W zapisach powyższej umowy znalazło się bowiem zobowiązanie Warcisława II do powstrzymywania

120 K. Jasiński, Gdańsk w okresie samodzielności politycznej..., s. 283. W przyp. 28 występuje błędny numer źródła (P, nr 236). Można jednak rozumieć, że chodziło o P, nr 235; idem, Pomorsko-krzyżackie uktady pokojowe z 1267 i 1268 roku, ZH 1982 , t. 47 , z. 4 , s. 103 . W przyp. 28 w pierwszej z wymienionych prac występuje błędny numer źródła (P, nr 236). Można jednak rozumieć, że chodziło o P, nr 235. Ten sam błąd popełnił J. Spors, Podziały..., s. 286, przyp. 10.

121 P, s. 191, przyp. 2 i 3; KKG, nr 117; M. Grzegorz, Stownik historyczno-geograficzny wójtostwa lęborskiego komturstwa gdańskiego w średniowieczu, Bydgoszcz 2013, s. 47.

122 J. Spors mógł tu mieć także na myśli wojewodę gdańskiego Dobiegniewa z lat 1267-1268, również wzmiankowanego w liście świadków. Według niego bowiem pochodził on właśnie z ziemi białogardzkiej i był tożsamy z tutejszym wojewoda z lat 80., co jednak jest dyskusyjne, zob. J. Spors, Nowa praca o roli politycznej mo $\dot{z}-$ nowładztwa na Pomorzu Gdańskim w czasach Mściwoja II, „Rocznik Koszaliński” 1988-89 (wyd. 1990), nr 22, s. 224; idem, Jeszcze o roli politycznej możnowładztwa na Pomorzu Gdańskim w czasach Mściwoja II, „Rocznik Słupski” 1990-1991 (wyd. 1992), s. 138-139; M. Szuba, Możni..., s. 130-131, gdzie dalsza literatura.

123 J. Spors, Podziaty..., s. 284-286. 
poddanych atakujacych ziemie i grody należące do zakonu. Badacz umieszcza je w ziemi białogardzkiej, formalnie należącej już wtedy do Krzyżaków, a zobowiązanie Warcisława II traktuje jako uznanie ich praw do darowizny Racibora. Później książę gdański miał zmienić zdanie i działać przeciwko zajęciu Białogardy przez zakon, czego przejawem byłoby nazwanie się księciem pomorskim, widoczne już 17 maja 1268 r., a także w omawianym dokumencie z 8 sierpnia tego roku. Zdaniem B. Śliwińskiego Warcisław II, stosując powyższą szeroką tytulaturę, chciał podkreślić swoje prawa do ziemi białogardzkiej ${ }^{124}$.

Pojawia się więc możliwość interpretacyjna, że być może tym samym celom co wyżej opisane miała służyć obecność Michała przy wystawieniu drugiego z wymienionych dokumentów. Podobnie można by tłumaczyć występowanie obok Michała na liście świadków rycerza Radzisława, którego obecnie lokalizuje się w Główczycach w ziemi słupskiej. Hipotetycznie identyfikuje się go także z wojewodą białogardzkim o imieniu Racław z 1257 r. ${ }^{125}$ Obaj więc, Radzisław i Michał, mogli reprezentować interesy swych ziem u boku Warcisława II $^{126}$. Obecność przedstawicieli ziemi białogardzkiej w otoczeniu Warcisława II i Mściwoja II, przy jednoczesnym braku tamtejszych urzędników, mogłaby także świadczyć o niedawnym przejęciu tego obszaru przez Świętopełkowiców. Jednak, jak wspomniano, odnoszenie wymienionych osób do ziemi przekazanej Krzyżakom nie jest pewne, ze względu na problem przynależności do kasztelanii białogardzkiej ziemi salińskiej. W takim wypadku obecność Radzisława można by wytłumaczyć tym, że dokument dotyczył spraw klasztoru bukowskiego, na co wskazał już J. Spors ${ }^{127}$. Rycerz ten bowiem był także świadkiem nadania dla tamtejszych cystersów z $1252 \mathrm{r.}^{128}$, choć B. Śliwiński przypuszczał, iż wynikało to jedynie ze stanu zachowania źródeł i wątpił w związki Radzisława z klasztorem

124 P, nr 222; B. Śliwiński, Mściwoj II..., s. 105-115, gdzie starsza literatura i przytoczenie dyskusji; zob. także A. Teterycz-Puzio, Polscy krzyżowcy. Fascynujaca historia wędrówek Polaków do Ziemi Świętej, Poznań 2017, s. 178-181; M. Smoliński, Świętopetk gdański..., s. 240-242. Sprawa darowizny Racibora i stosunku Warcisława II do tego aktu również wymaga bardziej szczegółowych badań.

125 B. Śliwiński, Rola polityczna możnowładztwa..., s. 40-41.

126 M. Szuba, Możni..., s. 133-134 (gdzie dalsza literatura dotycząca Radzisława), s. 138-139.

127 J. Spors, Podziaty..., s. 287.

$128 \mathrm{P}, \mathrm{nr} 135$. 
w Bukowie ze względu na odległość terytorialną od Główczyc ${ }^{129}$. Takiej możliwości nie można jednak wykluczyć.

Przed omówieniem karier duchownych słupskich należy zwrócić uwagę na kwestię przynależności politycznej tego ośrodka. Zdaniem, głównie dawniejszych, badaczy ziemia słupska po śmierci Świętopełka podlegała władzy Mściwoja II, jako księcia zwierzchniego całego państwa, lub była zarządzana przezeń wspólnie z Warcisławem II. Powoływano się tutaj m.in. na fakt, że obaj książęta wystawili omawiane w niniejszym artykule równobrzmiące dokumenty konfirmacyjne dla klasztoru w Bukowie, jednocześnie wzajemnie sobie na nich świadkując ${ }^{130}$. Jednak J. Spors, a za nim późniejsi historycy, osłabili ten argument, uznając dokonaną w tym dokumencie konfirmację dóbr klasztoru w Bukowie za wtórna wobec identycznego aktu księcia gdańskiego z 1268 r. Ponadto za przynależnościa ziemi słupskiej do Warcisława II przemawiałaby obecność w ostatnim z dyplomów wspomnianego Radzisława z Główczyc leżących na tym obszarze ${ }^{131}$. Co prawda później zasugerowano, że rycerz ów mógł tutaj reprezentować ziemię białogardzka jako jej wojewoda, co osłabiałoby powyższą argumentację ${ }^{132}$. Warto jednak zwrócić uwagę na podkreślenie $\mathrm{w}$ dokumencie z 1268 r. pochodzenia Radzisława, które mogło służyć manifestacji praw Warcisława II do ziemi słupskiej, podobne jak ogólnopomorski tytuł księcia. Również brak innych tamtejszych dostojników w Gdańsku wydaje się uzasadniony i nie musi zaprzeczać podległości tego terenu Warcisławowi II. Przemawiałaby za tym napięta sytuacja polityczna na zachodnich obszarach księstwa tego władcy, najpierw w związku z najazdem Barnima (lato 1266 r.), a później, przypuszczalnie, z darowizną Racibora dla zakonu krzyżackiego. Zmuszałaby ona dostojników słupskich do pozostania na miejscu. Również przeciwko przynależności ziemi słupskiej do dzielnicy Warcisława II nie przemawiałby ewentualny brak łączności

129 B. Śliwiński, Rola polityczna możnowtadztwa..., s. 41.

130 Kujot, s. 871-873; J. Powierski, Układ kamieński..., s. 11-12, przyp. 5; B. Włodarski, Świętopetk i Mściwój II..., s. 80. Została tutaj pominięta kwestia dyskusyjnej władzy zwierzchniej Mściwoja II. Na ten temat ostatnio na szerokim tle porównawczym wypowiedział się M. Smoliński, Primogenitus et dilectissimus..., s. 76-100 (szczególnie s. 89-100); idem, Świętopełk gdański..., s. 281-288; por. B. Śliwiński, Mściwoj II..., s. 102-103; M. Szuba, Stosunki zewnętrzne..., s. 196-198.

131 J. Spors, Podziaty..., s. 286-288.

132 B. Śliwiński, Rola polityczna możnowtadztwa..., s. 41. 
terytorialnej - taka bowiem mogła mieć miejsce krótko za rzadów Świętopełka, gdy istniała samodzielna dzielnica białogardzka Racibora (ok. 1233-1243/1244) ${ }^{133}$, choć ostatnio ją podważono ${ }^{134}$. Jest to jednak kwestia niejasna, ze względu na dyskusyjność dziejów ziemi białogardzkiej, także wcześniejszych. Rządy Warcisława II w Słupsku są więc prawdopodobne, nie należy jednak o nich mówić ze względu na brak bezpośrednich dowodów w postaci tytulatury czy dokonania tutaj czynności władczej.

Warto także zauważyć, że Warcisław II jeszcze za rządów Świętopełka zetknął się zapewne z duchowieństwem ze Słupska, gdzie w omawianym czasie miałyby istnieć trzy kościoły ${ }^{135}$. Był on również najprawdopodobniej obecny przy formalnej lokacji tamtejszego miasta na prawie lubeckim, powstałego z miejscowej gminy niemieckiej. Zdaniem B. Popielas-Szultki, które poparł B. Śliwiński, do tego aktu doszłoby w połowie sierpnia 1265 r., podczas podróży Świętopełka do Sławna, gdzie 31 tego miesiąca wystawił dokument dla klasztoru w Bukowie. Został w nim wymieniony także Warcisław II, co pozwala przypuszczać, że towarzyszył ojcu także w Słupsku ${ }^{136}$.

Również w dokumencie z 3 maja 1269 r. pojawiaja się dwaj duchowni słupscy: Chrystian i Herman. Pierwszy z nich został wymieniony jako kapelan w miejscowym grodzie. Mógł posługiwać w kaplicy grodowej, znanej jednak pod wezwaniem Najświętszej Marii Panny dopiero od 1281 r. Duchowny ten pojawia się jeszcze raz

133 J. Spors, Podziaty..., s. 114-115, 270, 280-283, 284-288; M. Smoliński, Księstwo białogardzkie..., s. 80-81.

134 B. Śliwiński, Sambor II ksiaże tczewski (1211 lub 1212 - 30 grudnia 1276/1278), wyd. 2, Kraków 2015, s. 64.

135 Oprócz omówionych niżej byłby to także kościół w osadzie przygrodowej pw. św. Piotra. Pierwsza wzmianka o nim pochodzi jednak również dopiero z 1281 r., zob. J. Spors, We wczesnofeudalnym księstwie stawieńsko-stupskim i gdańsko-pomorskim w XII-XIV wieku [w:] Historia Stupska, red. S. Gierszewski, Poznań 1981, s. 55, 67; idem, W sprawie poczqtków miasta lokacyjnego w Stupsku, „Rocznik Słupski” (dalej: RS) 1984, s. 11-13; idem, O poczatkach lokacji miasta w Stupsku ze szczególnym uwzględnieniem problemu najstarszej osady stupskiej, RS 1990-1991 (wyd. 1992), s. 21-22, 43.

136 P, nr 208; B. Popielas-Szultka, Lokacja..., s. 14-15; eadem, Poczatki i lokacje miast na Pomorzu Stawieńsko-Stupskim do połowy XIV wieku, Słupsk 1990, s. 49-55; B. Śliwiński, Msciwoj II..., s. 97-98, gdzie starsza literatura; M. Smoliński, Świętopetk gdański..., s. 183-184; H. Jurkiewicz, Ziemia stawieńsko-stupska w planach i polityce Świętopetka Wielkiego [w:] Polska i sasiedzi na przestrzeni wieków. Prace doktorantów historii, t. 2: Na wojnie i w czasach pokoju, red. W. Skóra, A. Teterycz-Puzio, Słupsk 2018, s. 58. 
w 1274 r., określony tym razem tylko jako „capellanus noster”, czyli książęcy. Barbara Popielas-Szultka utożsamia jeszcze Chrystiana z osobą o tym imieniu wzmiankowaną w 1240 r., wbrew J. Sporsowi, który uznawał ją za przedstawiciela miejscowej gminy niemieckiej ${ }^{137}$.

Herman z kolei został w 1269 r. określony kapelanem kościoła w mieście słupskim (dosł. „naprzeciwko grodu”). Badacze widzą w tej świątyni kościół św. Mikołaja, także znanym pod tym wezwaniem od 1281 r. Obsługiwał on gminę niemiecka, z której powstało miasto, choć jest dyskusyjne, czy pełnił funkcję kościoła parafialnego. Nie do końca jest też wyjaśniony charakter prawny tej świątyni, bowiem według B. Popielas-Szultki stanowiła ona prywatny kościół księcia, nad którym ten posiadał prawo patronatu, mógł więc wyznaczać jej duchownego. Józef Spors ograniczył się z kolei do stwierdzenia, że kościół ten został ufundowany i wybudowany przez Świętopełka dla gminy niemieckiej ${ }^{138}$. Niemniej zdaniem obu badaczy Herman byłby duszpasterzem tej wspólnoty i z tego powodu oraz ze względu na imię przypisywano mu w literaturze niemieckie pochodzenie. Historycy wiążą także duchownego słupskiego z kapelanem Świętopełka z 1240 r. ${ }^{139}$ Nie należy również utożsamiać Hermana z 1269 r. z kapelanem gdańskim, co opisano wyżej.

Gdyby przyjąć powyższe ustalenia, obaj kapelani - Chrystian i Herman - podobnie jak w wypadku gdańskich duchownych, byliby przypuszczalnie powoływani przez księcia i od nich zapewne zależni. Obaj także posługiwali zarówno za czasów Świętopełka, jak i Warcisława II, co mogłoby przemawiać za uznaniem przynależności Słupska do drugiego z książąt, choć nie w sposób przesądzający. Chrystian bowiem posługiwał także za rządów Mściwoja II. Fakt ten mógłby sugerować, podobnie jak w omówionych wyżej wypadkach, że duchowny ten poparł starszego $\mathrm{z}$ braci podczas wojny domowej. Wynikałoby z tego, iż Herman zachował się inaczej, przez co utracił swoją funkcję. W tym miejscu należy jednak uwzględnić hipotezę B. Śliwińskiego, według której

137 P, nr 70, 330; B. Popielas-Szultka, Rozwój przestrzenny..., s. 173-174, 180-181; J. Spors, Kwestia datowania..., s. 36.

138 B. Popielas-Szultka, Poczatki i lokacje miast..., s. 60; J. Spors, Kwestia datowania..., s. 36-39; por. W. Abraham, Poczatki prawa patronatu..., s. 11-12.

139 J. Spors, Z problematyki trzynastowiecznego Stupska. Kościoły stupskie na tle aglomeracji osadniczej, ZH 1978, t. 43, z. 1, s. 16-18; idem, Kwestia datowania..., s. 35-38; idem, O poczqtkach lokacji..., s. 33; B. Popielas-Szultka, Lokacja..., s. 12, 18; eadem, Poczatki i lokacje miast..., s. 50-51, 60. 
książę rugijski Wisław II w 1270 r., a więc w trakcie wojny między Świętopełkowcami, zajął nie tylko ziemię sławieńska, ale także słupska. Chrystian, zdaniem tego badacza, należałby do grona osób, które pomogły odzyskać władzę Mściwojowi II nad Słupskiem w 1274 r., podobnie jak znani już wcześniej dostojnicy świeccy, np. sędzia Jakub i podkomorzy Święca ${ }^{140}$. Gdyby przyjąc tę hipotezę za prawdziwa, drugi z duchownych, Herman, mógłby równe dobrze zostać odwołany przez Wisława II. Hipoteza ta potwierdzałaby jednak, że Herman, jako proboszcz związany z miastem słupskim, mógł wspierać działania Wisława II. Ten ostatni bowiem wspierał lubeczan i lokował miasta m.in. w podbitej ziemi sławieńskiej w Darłowie ${ }^{141}$. Nasuwa się tutaj podobieństwo do sytuacji w Gdańsku, gdzie wspomniana grupa społeczna poparła przejęcie Gdańska przez margrabiego Konrada, za co jednak później mieszczanie byli represjonowani przez Mściwoja II. Przemawia za tym także osłabienie darłowskiego miasta przez Mściwoja ${ }^{142}$. Być może Herman także z podobnych przyczyn popadł w niełaskę i zostałby odwołany. Brak jednak dowodów na taki obraz jego losów. Niewykluczone, że w 1274 r. już nie żył.

Zdaniem B. Śliwińskiego kolejnym słupskim duchownym, związanym z wydarzeniami z 1274 r., był Jan, notariusz Mściwoja II. Jego przejście do książęcej kancelarii badacz umieszcza w krótkim okresie po zdobyciu Słupska ${ }^{143}$. Na wspomnianym stanowisku, a jednocześnie po raz pierwszy w źródłach, Jan był wzmiankowany już $\mathrm{w} 1275 \mathrm{r}$. w tym samym grodzie ${ }^{144}$. Pojawia się więc od razu pytanie, czy nie posługiwał on tutaj także za czasów Warcisława II. By na nie odpowiedzieć, należy zwrócić uwagę na dalszą karierę duchownego, a szczególnie na kwestie chronologiczne. Historyk oparł się tutaj na ustaleniach A. Gut ${ }^{145}$, która za J. Maciejewskim ${ }^{146}$ zwróciła uwagę na występowanie Jana jako notariusza w ośrodkach zachodnich ziem państwa Mściwoja II do 1288 r., kiedy także po raz ostatni

140 B. Śliwiński, Mściwoj II..., s. 209-210.

141 Ibidem, s. 145-146; J. Powierski, Pierwsza lokacja Dartowa i IV powstanie Prusów jako przejawy polityki Wisława II rugijskiego, „Darłowskie Zeszyty Naukowe" 2002, nr 7, s. 4.

142 B. Śliwiński, Mściwoj II..., s. 10, 163-167, 171-175, 184-187, 292-294.

143 Ibidem, s. 209-210.

144 P, nr 270.

145 A. Gut, Średniowieczna dyplomatyka..., s. 114-115.

146 J. Maciejewski, Kościót i duchowieństwo..., s. 67-68. 
wystapił w Słupsku ${ }^{147}$. Ponadto wskazała na możliwość jego posługi w którymś z miejscowych kościołów: św. Mikołaja lub raczej kaplicy grodowej. To właśnie przekazanie prawa patronatu nad ta światynią w $1281 \mathrm{r}$. norbertankom i wywieranie później przez mniszki wpływu na wybór duchownych badaczka uznaje za możliwa przyczynę przejścia Jana do Świecia nad Wisłą na początku lat 90. XIII w. Podobnie jak J. Maciejewski identyfikuje go bowiem z tamtejszym plebanem, wzmiankowanym po raz ostatni w 1293 r. ${ }^{148}$ Zdaniem obojga historyków przeniesienie Jana do Świecia na stanowisko plebana stanowiłoby także nagrodę za dotychczasową służbę. Tamtejsza grupa kanonicka cieszyła się bowiem za czasów Mściwoja II większym uznaniem władcy i przejęła znaczenie gdańskich kapelanów, także w kancelarii ${ }^{149}$. Tak długa aktywność Jana mogłaby osłabić sytuowanie początków jego kariery już za czasów Warcisława II, biorąc za przykład omówione wyżej kariery duchownych gdańskich: Hermana, Wacława i Ludera. Wątpliwości budziłoby przejście Jana do Świecia w tak późnym wieku. Dotyczyłoby to jednak także sytuacji, gdyby ograniczyć działalność duchownego do Słupska i 1288 r. Niemniej obie przesłanki nie wykluczają całkowicie tego, że działał on w tym ośrodku już przed 1269 r., choć w takim wypadku zapewne dopiero zaczynał swoją posługę. Możliwość taka uprawdopodabnia pogląd, według którego Jan poparłby Mściwoja II i został przez niego mianowany notariuszem, choć zapewne urzędującym w Słupsku. Byłby to także początek właściwej kariery Jana.

Podsumowujac niniejsze rozważanie, można zaproponować następujące wnioski:

1) Zbadany materiał źródłowy potwierdza współpracę Warcisława II i duchowieństwa, przede wszystkim gdańskiego. Świadczy o tym nie tylko występowanie ich na dokumentach tego władcy, ale także uznawanie za pomocą tytułów za osoby funkcyjne księcia: kapelanów, kleryków notariuszy. Stanowiliby oni więc personel administracyjny księcia. Czołową rolę odgrywała tu grupa kanonicka przy kościele grodowym.

$147 \mathrm{P}, \mathrm{nr} 435$.

148 P, nr. 501, 503; A. Gut, Średniowieczna dyplomatyka..., s. 114-115. W sprawie daty drugiego z wymienionych w niniejszym przypisie dokumentów zob. Z. Górski, Itinerarium Mszczuja II (1264-1294), „Acta Universitatis Nicolai Copernici. Nauki Humanistyczno-Społeczne. Historia” 1973, t. 8, z. 54, s. 122, przyp. 123.

149 A. Gut, Średniowieczna dyplomatyka..., s. 114-115; J. Maciejewski, Kościót i duchowieństwo..., s. 67-68. 
2) Szczególną funkcję zdawali się pełnić duchowni kościoła św. Katarzyny w Gdańsku, związanego z miastem na prawie lubeckim. Świadczy o tym występowanie przedstawiciela tej parafii - Ludera, zarówno u boku Warcisława II, jak i niechętnego mieszczanom Mściwoja II. Mogło to wynikać z przyczyn politycznych, o czym w następnym punkcie, ale także ich umiejętności dyplomatycznych czy kancelaryjnych. Te ostatnie sa jednak zauważalne dopiero za Msciwoja II.

3) Duchowieństwo mogło także brać udział w życiu politycznym i odgrywać w nim istotna rolę. Widać to na przykładzie plebana kościoła św. Katarzyny, który uczestniczył w ważnych dla Warcisława II kontaktach z mieszczanami gdańskimi, być może jako pośrednik lub reprezentant interesów tych ostatnich. Niewykluczone więc, że miał on wpływ na decyzję władcy i kształtowanie niektórych kierunków polityki.

4) W wypadku duchowieństwa słupskiego, ze względu na skromność źródeł, można ograniczyć się do stwierdzenia, że odgrywało głównie lokalną rolę. Nie występowała tu jeszcze osobna książęca kancelaria, o czym świadczy spisanie wystawionego w Słupsku dokumentu przez notariusza ze Świecia. Miejscowy notariusz pojawił się dopiero za czasów Mściwoja II i być może zaczynał za Warcisława II posługę duchowna. Słupskie duchowieństwo mogło natomiast odegrać dużą rolę podczas zmian przynależności Słupska, co widać na hipotetycznym przykładzie odzyskania Słupska przez Mściwoja II w 1274 r. Być może było ono politycznie aktywne także podczas wydarzeń wojny domowej z lat 1269-1271, choć brak na to dowodów.

5) Można uznać za prawdopodobną utratę stanowisk przez część duchownych po przejęciu w księstwie Warcisława II władzy przez Mściwoja II. Niewykluczone, że wynikała ona z przyczyn politycznych. Brakuje jednak na to pewnych dowodów.

6) Również obecność Michała z Salina w otoczeniu Warcisława II mogła mieć przyczyny polityczne i oznaczać manifestację władzy w ziemi białogardzkiej lub roszczenia do tego obszaru. Może także świadczyć o istnieniu już wtedy związków Salina z gdańskim szpitalem św. Ducha, o ile nie był on mnichem benedyktyńskim powiązanym z prepozytura św. Wojciecha pod Gdańskiem. 


\section{Abstract \\ Clergy in the State of Warcisław II, Duke of Gdańsk}

(1266-1269/1270)

The above paper deals with the clergy in the state of Warcisław II, Duke of Gdańsk and East-Pomerania between 1266 and 1269/70. The careers of representatives of this class are reconstructed by collecting and verifying source information and the extensive discussions of earlier historians. Four clergymen from Gdańsk, 2 from Słupsk, and Michael priest of "Saulyn" have been authenticated, but it is not certain that the last two places actually belonged to Warcisław's state.

The main conclusion of this research is that during the reign of Warcisław II, clergy were of political significance. They served in administration and in an early chancellery service, as in the case of a group of clergy in the fortified church in Gdańsk. It is likely that one of local priests- Wacław/Unisław - was also probably related to an influential gentry family This was also probably the case with Luder, priest of St. Catharine's Church in the city of Gdańsk. He was probably an agent mediating between the Duke and the middle class. Warcisław II had good relations with the middle class and its political influence was growing during his reign. In Słupsk, too, the clergy participated in changing political affiliations, but that is visible only later. Clergymen also supported other dukes; this was visible and of importance during the East-Pomeranian civil war (1269-1271) between Warcisław II and Msciwoj II, which ended in the former's exile.

One historian believes that the priest Michael served in Salino in East-Pomerania. Perhaps his presence in a privilege from 1268 had a political context - by that act Warcisław II could show his claims to Białogarda's land. This had been mortgaged to the Teutonic Order by Duke Racibor. Otherwise, according to the opinion of Klemens Bruski, Michael could have served in another place - Słona near Kościerzyna. 